\title{
THE STRUCTURE OF THE GYNOSTEGIUM, BREEDING SYSTEM, AND POLLINATION ECOLOGY OF SPIDER MILKWEED, ASCLEPIAS VIRIDIS WALTER (APOCYNACEAE)
}

\author{
Master's Thesis \\ University of Central Oklahoma \\ 1999
}

\author{
Shang-Wen Liaw \\ Department of Biology \\ University of Central Oklahoma \\ Edmond, OK 73034 \\ Correspondence to: gcaddell@uco.edu
}

Keywords: phenology, reproduction, electron microscopy, self-incompatibility

\begin{abstract}
Reproductive structures, flowering phenology, breeding system, and potential pollinators were described in two populations of Asclepias viridis Walter in Oklahoma in 1997 and 1998. Scanning electron microscopy was used to locate the stigmatic surfaces of the gynostegium, and a series of pollination treatments was performed including open-pollination, supplemental pollination, self-pollination, and within- and between-population cross-pollination. Flower visitors, their visitation rates, and numbers of pollinaria carried were recorded. Pollinia were inserted in four ways to determine which type of insertion results in pollen germination, and flowers were collected to determine how pollinia were inserted by insects. The stigmatic surfaces of $A$. viridis are located at the fusion point of the two styles at the base of the gynostegium. Selfpollinations produced no mature follicles, revealing self-incompatibility. In addition to genetic barriers, the low rate of natural fruit-set (1.87\% in 1997 and $1.39 \%$ in 1998) is due to follicle abortion and predation of flowers and follicles. Supplemental pollination did not significantly increase fruit and seed set. Fruit-set from hand cross-pollinations at one site, but not the other, revealed a greater crossability between populations than within. A. viridis flowered from early May to late June, with a peak in late May. The mean number of flowers per inflorescence was 34.1, and the mean flowering span per inflorescence was 10.6 days. Over 20 families of insects, including those within the orders Hymenoptera, Lepidoptera, Coleoptera, and Hemiptera, visited flowers. Of the hymenopterans, solitary wasps, large carpenter bees, digger bees, and bumblebees carried pollinaria. Hymenopterans contributed the majority of visitations, and bumblebees (Bombus spp.; Apidae) were the most important pollinators based on numbers of pollinaria carried and frequency of visitation. The highest percentage of mature follicles was obtained when pollinia were inserted with the convex edge toward the stigmatic surface; natural pollinators almost always insert pollinia in this manner.
\end{abstract}

Editor's Note: Where nomenclature has been updated using ITIS-Integrated Taxonomic Information Service (http://www.itis.gov), the original name is in brackets [ ]. 


\section{INTRODUCTION}

Asclepias (Apocynaceae) is a widespread genus with at least 108 species distributed in North America and the Antilles (Woodson 1954). Because of its floral complexity, it is considered a herkogamous genus, and pollination within natural populations is apparently dependent upon insect visits. The floral structure of Asclepias has been described in detail by several authors (Woodson 1947; Sparrow and Pearson 1948; Wyatt 1976; Sundell 1984; Morse 1987). Five antisepalous stamens are highly modified and fused with the stigmatic head to form a unique reproductive column called the gynostegium. A pair of coriaceous protruding flaps, or anther wings of two adjacent anthers, form a vertical slit along the gynostegium and open into a stigmatic chamber.

Five slits are arranged on the gynostegium. Each anther has two vertical pollen sacs (Woodson 1954), each of which contains a pollen mass called a pollinium. A pair of pollinia, from pollen sacs of two adjacent anthers, is joined by two ascending translator arms to a hollow, black, grooved body called the corpusculum located above the slit. The entire unit, which includes a pair of pollinia, a pair of translator arms, and the corpusculum, is called the pollinarium or the bipollinium (Newton 1984). The hoods or appendages of the five stamens join and surround the gynostegium, forming a corona. Each hood contains nectar and in some species contains an incurving structure called the horn. Two ovaries are located at the base of the flower above the calyx, and their two styles protrude and fuse to form a flat mass of tissue below the stigmatic head. According to Woodson (1947) and Wyatt (1976), however, the stigmatic surface is not at the flat top of the gynostegium but is actually shifted laterally and divided into five concave surfaces at the base of the five stigmatic chambers. This description appears to differ from Brongniart's illustration in 1832 (Sundell 1984), which indicates that the stigmatic surfaces may be located at the base of the gynostegium where the two styles are fused. According to Kevan et al. (1989), the nectaries of Asclepias are actually the walls of the stigmatic chambers, and concentration of nectar in the stigmatic chamber may either stimulate or inhibit pollen germination. Based on the similarities between constituents of nectar and stigmatic secretions (Kearns and Inouye 1993), staining may lead to a misinterpretation of the location of the stigmatic surface.

A depression or furrow is found on the flat top of the gynostegium in some Asclepias species; pollen tubes that enter stigmatic surfaces in three chambers on one side of the depression can reach one ovary, and pollen tubes reach the other ovary from the other two adjacent chambers (Broyles and Wyatt 1993). However, in some species, two follicles occasionally result from handpollination with a single pollinium (Kephart 1981; Morse 1993). Sage et al. (1990) assumed that the crossover may occur at the point at which the two styles are fused or during the growth of pollen tubes down the stylar canal. Consequently, to exactly locate the stigmatic surfaces and solve the mystery of the production of twin follicles, anatomical observation of the gynostegium is warranted.

Various vectors, mostly polytropic Hymenoptera and Lepidoptera (Macior 1965; Morse 1985), are presumably attracted by the abundant nectar secreted by Asclepias species (Willson and Bertin 1979; Willson et al. 1979). As insects forage on flowers, they remove pollinaria from the pollen sacs by hooking the corpusculum channel onto various body regions. Depending on the morphology of the various taxa of insects, pollinaria may attach to mouth parts, claws, pulvilli, tibiae, and tarsi. They often form complicated chains or masses as the corpusculum channel of one pollinarium 
hooks to a translator arm of another pollinarium (Frost 1965; Macior 1965). After a pollinarium is removed from a flower, the pollinia may dry in the air. The translator arms twist and rotate the pollinia 90 degrees so they can be easily inserted into the stigmatic chambers of other flowers (Kephart 1981). As insects move on flowers after landing, pollinia are precisely inserted into the stigmatic chambers. According to Wyatt (1976), who observed over 500 pollinia insertions of $A$. tuberosa L., insertion does not occur simply by chance but is more likely to be a specific process because, except rarely, all pollinia were inserted entirely inside the stigmatic chambers, and the convex surface of a pollinium was always brought into contact with the stigma. Whether all insect vectors show the same manner of pollinium insertion in other Asclepias species has never been reported. Therefore, the manner of pollinium insertion accomplished by insect vectors in relation to fruit-set of Asclepias within natural populations should be investigated further.

Because of the complex floral structure of Asclepias, many aspects of species in this genus have been investigated in past decades, including their breeding systems (e.g., Sparrow and Pearson 1948; Wyatt 1976; Kephart 1981; Broyles and Wyatt 1993; Shore 1993; Gold and Shore 1995); their floral biology, pollination ecology, and evolutionary ecology (e.g., Willson and Price 1977, 1980; Bookman 1983a, 1983b; Broyles and Wyatt 1991; Pleasants 1991; Fishbein and Venable 1996); and their reproductive biology in relation to the adaptations and behavior of insects (e.g., Frost 1965; Macior 1965; Willson and Rathcke 1974; Willson and Bertin 1979; Willson et al. 1979; Bertin and Willson 1980; Willson and Price 1980; Morse 1987; Jennersten and Morse 1991). In addition, aspects of their physiology, such as dormancy and germination of seeds, have also been studied (e.g., Oegema and Fletcher 1972; Baskin and Baskin 1977).
According to Wilber (1976), most species studied had a very low level of self-fertility as determined by the results of breeding system experiments. Sparrow and Pearson (1948) found that only two follicles developed from 1,354 hand self-pollinations in populations of $A$. syriaca L. However, they explained that one was certainly the result of the accidental introduction of foreign pollen by a bee, and the other was abnormal because most of its seeds were aborted and undersized. Wyatt (1976) selfpollinated 112 flowers in five different populations of $A$. tuberosa. Self-compatibility ranged from $0 \%$ to $9 \%$, with a mean of $1.8 \%$. Kephart (1981) reported the results of self-pollination treatments for three Asclepias species: none of 55 self-pollinated flowers from three populations of $A$. verticillata $\mathrm{L}$. produced mature follicles; an average of $4.2 \%(3 / 73)$ of self-pollinated flowers produced follicles from two $A$. syriaca populations; and in seven populations of A. incarnata L., an average of $29.2 \%$ of selfpollinations produced follicles. Bookman (1984) found that only two A. speciosa Torr. ovaries fully matured into follicles among 240 hand self-pollinated flowers and concluded that $A$. speciosa populations have a few rare, self-compatible individuals. Broyles and Wyatt (1993) stated than none of 138 hand self-pollinated flowers in an A. exaltata L. population produced mature follicles. However, it is difficult to compare the degree of self-fertility among species because of the variation in techniques used by different researchers. For example, Bookman (1984) used pollinia inserted into the first, third, and fifth of the five stigmatic chambers per flower so that ovules of both ovaries could potentially be fertilized; whereas, Broyles and Wyatt (1993) used pollinia inserted into the fourth and fifth chambers so that ovules in only one of two ovaries could presumably be fertilized.

Many factors, such as light intensity, precipitation, temperature (Wyatt 1976; Waser 1983), leaf surface for photosynthesis 
and soil nutrients (Pleasants 1980), insufficient pollination (Wyatt 1976), and nectar concentration affecting pollen germination (Kevan et al. 1989) may influence the reproductive success of plant species. Woodson (1954) proposed that a relatively low rate of natural fruit-set, about $1 \%$, occurs in almost all species of Asclepias. In a field study of follicle production in five populations of $A$. speciosa, Bookman (1984) found that only an average of $2.4 \%$ of all ovaries developed into mature follicles. Shannon and Wyatt (1986) found that an average of $2 \%$ fruit-set occurred in four populations of $A$. exaltata. Although spatial separation of anthers and stigmas and genetic self-incompatibility systems in angiosperms promote outcrossing, they may also be responsible for the low level of fruitset in natural populations, especially in Asclepias (Broyles and Wyatt 1993). With such a high degree of spatial separation of pollen sacs and stigmas, Asclepias requires insects to accomplish pollination (Sparrow and Pearson 1948), and the efficiency of pollination often depends upon agreement of flower size and form with body form and behavior of insect pollinators (Macior 1965). Genetic self-incompatibility causes rejection of self-pollen (Broyles and Wyatt 1993), and a high rate of insect-mediated selfpollination has been suggested to contribute to the low natural fruit-set in Asclepias (Wyatt and Broyles 1994). Systems of selfincompatibility are generally classified as sporophytic and gametophytic (Kearns and Inouye 1993; Wyatt and Broyles 1994). However, a sporophytic incompatibility system seems unlikely to occur in Asclepias because its pollen grains are always able to germinate in the stigmatic chambers with the presence of favorable nectar concentration under natural conditions (Kevan et al. 1989). Consequently, a gametophytic incompatibility system, in which pollen tubes are usually arrested in the style, more likely occurs in Asclepias. Shore (1993) concluded that the rate of natural self-pollination in a population of A. syriaca was $66 \%$.

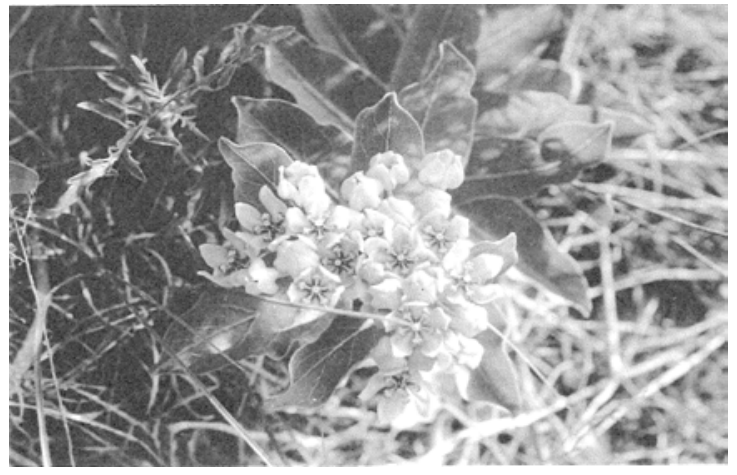

Figure 1 The spider milkweed (Asclepias viridis)

A. viridis Walter, a herbaceous perennial commonly called spider or green milkweed (Figure 1), is distributed from Tennessee to Florida and westward to Nebraska and eastern Texas. In general, its inflorescence is a terminal and solitary compound umbel usually composed of 2-4 umbellets. Differing in some morphological aspects from many other Asclepias species, the flower of $A$. viridis has inflexed petals and no horn contained in the hood. Most of its populations are distributed within Kansas, Missouri, Oklahoma, Arkansas, and Texas (Woodson 1954). It is usually found along railroads, on roadsides, in abandoned fields, within disturbed prairies, and on dry hillsides in summer. It flowers from April to August.

There are no published reports on the reproductive biology and the pollination ecology of $A$. viridis. The purpose of this study is to describe the reproductive structures, flowering phenology, breeding system, and potential pollinators of A. viridis. Specifically, I asked the following questions: (1) Where are the stigmatic surfaces located within the gynostegium; (2) What is the flowering period of $A$. viridis in central Oklahoma; (3) What is the phenology of individual flowers and inflorescences; (4) Does A. viridis show a 
low level of self-compatibility as do other Asclepias species; (5) Does $A$. viridis demonstrate the low level of natural fruit-set exhibited by other Asclepias species, and if so, is it due to lack of pollination, lack of compatible pollen reaching stigmas, or lack of resources for follicle development;

(6) Which insects visit frequently, carry pollinaria, and position themselves on the gynostegium so that they can be considered potential pollinators; (7) How are pollinia inserted into stigmatic chambers by natural pollinators; and (8) What type(s) of insertion can lead to pollen germination?

\section{METHODS AND MATERIALS}

\section{Study Areas}

Two populations of $A$. viridis were studied, the Arcadia Lake population (ALP) and the Bryant-Simmons population (BSP), separated by a distance of about $12.8 \mathrm{~km}$ [8 mi] (Figure 2). Most investigations were conducted at the ALP site (Figure 3). This study site (320 m [1050 ft] elevation) is a recovering grazed prairie on the shore of Lake Arcadia, $3.2 \mathrm{~km}$ [2 mi] east of I-35 on the south side of 15th Street (T13N R2W, Sec. 3), Edmond, Oklahoma County, Oklahoma. The western and northwestern sides of this area are both bounded by a crosstimber forest dominated by Quercus stellata Wangenh. and Q. marilandica Münchh. This research area slopes gradually from the center towards its southeastern boundary into Lake Arcadia. A residential area is adjacent to its northern boundary. It was heavily grazed by cattle until the early 1980s but is recovering towards a tallgrass prairie dominated in the fall by several native perennial species, such as Schizachyrium scoparium (Michx.) Nash [Andropogon scoparius Michx.], Bothriochloa saccharoides (Sw.) Rydb. [A. saccharoides Sw.], and Sorghastrum nutans (L.) Nash. On the other hand, many invaders, such as Amphiachyrias dracunculoides (DC.) Nutt. [Gutierrezia dracunculoides (DC.) S.F. Blake] and Ambrosia spp., still remain.
In addition, the woody species Juniperus virginiana $\mathrm{L}$. has invaded the site since the early 1980s. The BSP site (351 m [1150 ft] elevation), in contrast to the ALP site, is a relatively flat pasture and is privately owned (Figure 4). It is located at the northeast corner of Bryant Avenue and Simmons Road (T15N R2W, Sec. 30) in northern Edmond, Logan County, Oklahoma. This site was utilized only for the intra- and interpopulation cross-pollination study.

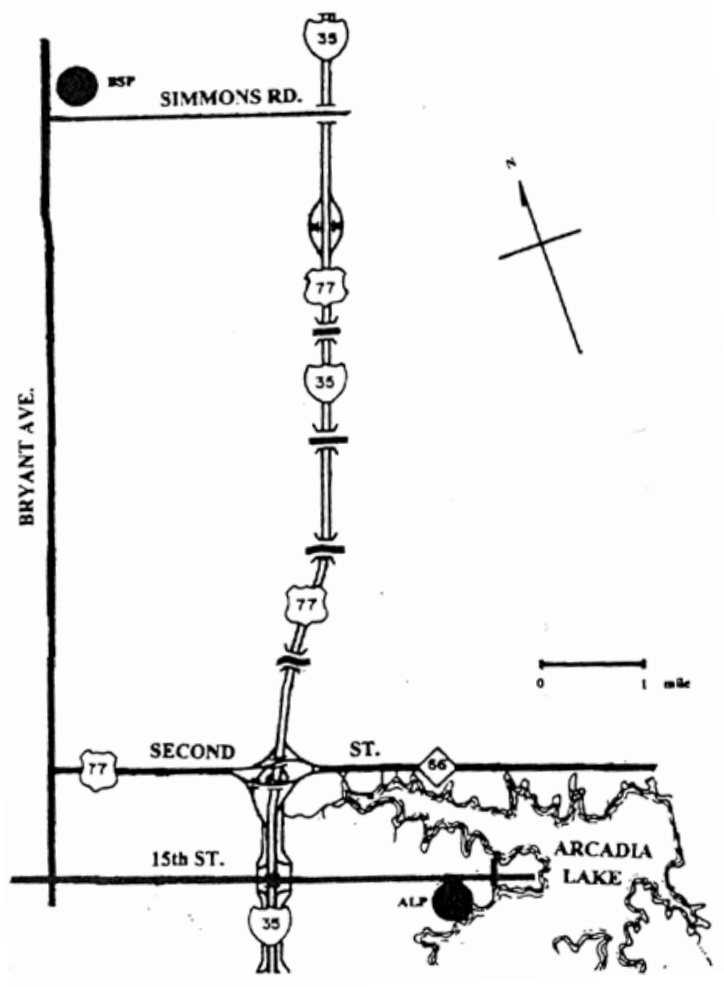

Figure 2 Locations of the UCO Lake Arcadia Research Area (ALP) and the Bryant Avenue-Simmons Road site (BSP). 


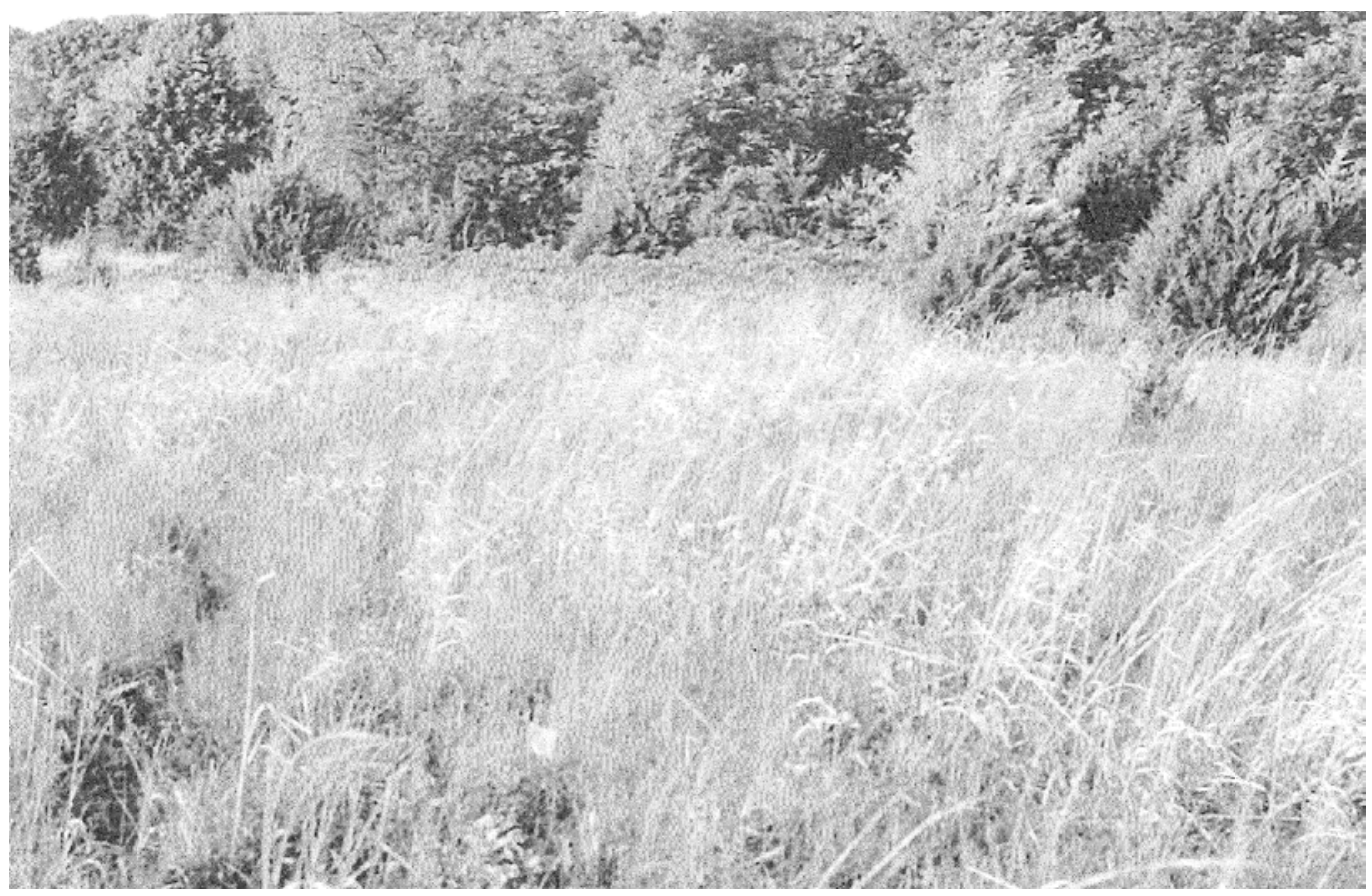

Figure 3 The western edge of the UCO Lake Arcadia Research Area (ALP). It is bounded by Quercus stellata and Q. marilandica.

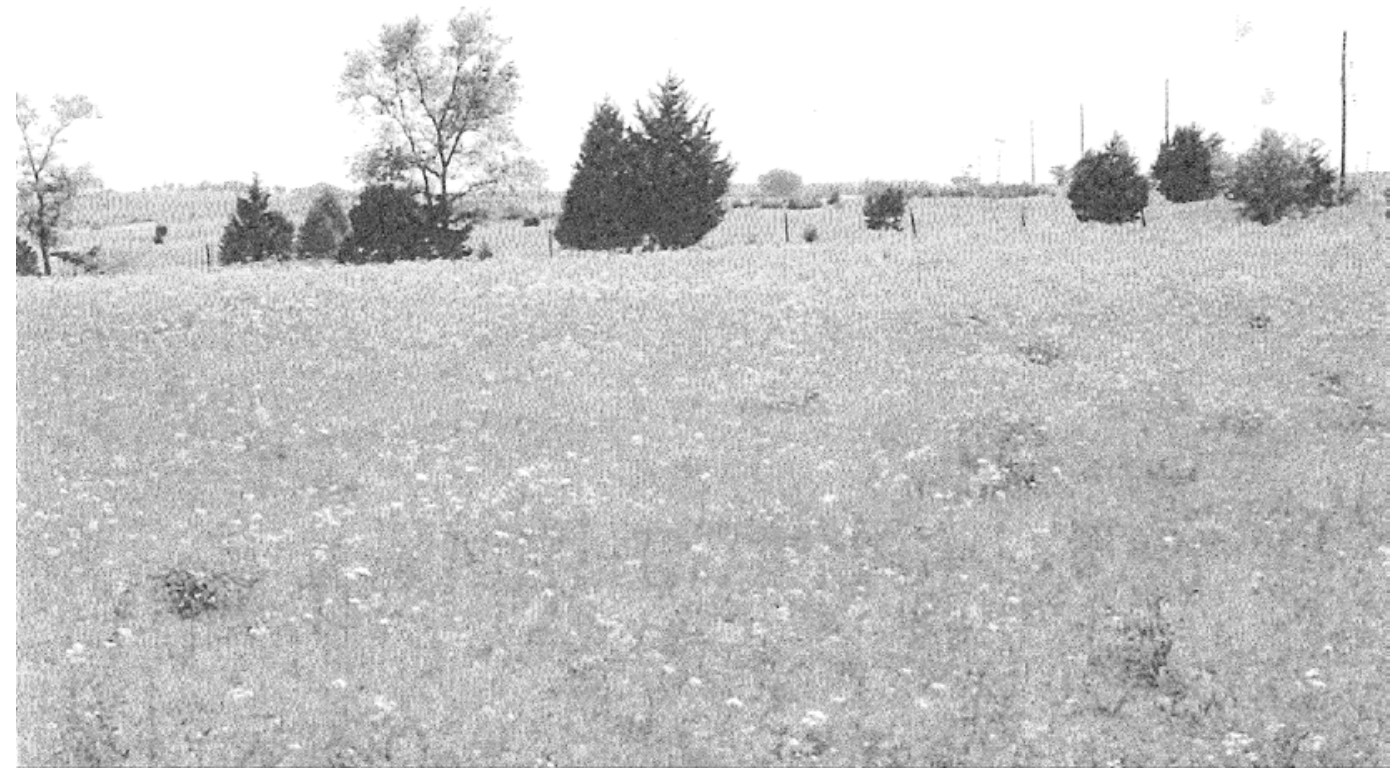

Figure 4 The Bryant-Simmons study site (BSP). This flat pasture is located at the northeast corner of Bryant Avenue and Simmons Road in northern Edmond, Logan County, Oklahoma. 


\section{Anatomical Structure of the Gynoecium}

In order to locate the stigmatic surfaces, several flowers, some with insertions of pollinia, were collected from the ALP site. Flowers were dissected in several ways with a surgical razor blade to expose the entire gynoecium while they were still fresh. I used the method suggested by Ciampolini et al. (1990) but fixed specimens in 5\% instead of $3 \%$ glutaraldehyde in $0.006 \mathrm{M}$ cacodylate buffer at $\mathrm{pH} 7.2$ and for $12 \mathrm{~h}$ instead of $3 \mathrm{~h}$. Then the fixed specimens were dehydrated through an ethanol series $(25 \%-1 \mathrm{~h} ; 50 \%-1$ h; 75\%-1 h; 95\%-1 h; and 100\%-1 h). The specimens then were critical-point dried (SAMDRI-790A CPD, Tousimis Instrument, Rockville, Maryland) at 7391 $\mathrm{kPa}$ [1072 psi] and $31.1^{\circ} \mathrm{C}$. Ethanol of $100 \%$ purity was used as an intermediate fluid, and liquid carbon dioxide was used as a transitional fluid during processes. After complete dehydration, specimens were mounted on metal specimen stubs by using silver paint as the adhesive and stored in a desiccator for $24 \mathrm{~h}$. Finally, specimens were coated using a Hummer 10.2 Sputter Coater (Anatech, Ltd., Alexandria, Virginia) to achieve a $15 \mathrm{~nm} \mathrm{Au} / \mathrm{Pd}$ coating and examined under a LEO S420 scanning electron microscope (SEM, LEO, Inc., Cambridge, England).

\section{Breeding System}

The degree of stigma receptivity and pollen viability may vary with age of the flower and may differ among Asclepias species (Bookman 1983b; Morse 1987). To ensure pollen germination and stigma receptivity for hand-pollination treatments, several pollinia were collected from 1-, 2-, and 3-day-old flowers at the beginning of the 1998 flowering searson. Pollinia were incubated on agar plates consisting of 10\% cane sugar and 2\% agar (Kephart 1981) to check for pollen germination. After 4-hour incubation, the pollen tubes from 2-day-old flowers seemed to have longer pollen tubes. Therefore, I used pollinia from 2-day-old flowers for all hand-pollination treatments. Additionally, 1-, 2-, and 3-day-old flowers were collected, and 3\% hydrogen peroxide was applied to check peroxidase activity of the stigma by the presence of a bubbling action (Kearns and Inouye 1993). Unfortunately, there was no apparent bubbling action on any flower. Therefore, I used 1- or 2-day-old flowers for all handpollinations, as the younger flowers have a higher stigma receptivity as suggested by Morse (1987).

Open pollination was observed and data were collected at the ALP site in 1997 and 1998 to estimate the level of natural fruitand seed-set. To obtain an estimate of the overall percentage of fruit-set throughout the flowering season, the flowering season was divided into three periods: April 16May 15, May 16-June 14, and June 15-July 14. At the beginning of each period, 20-30 stems with well-developed umbels were selected from the ALP site and tagged before flowers opened. No more than two stems per plant were sampled, and only one stem was sampled if a plant had fewer than six stems. Number of flowers on all sampled stems was counted and multiplied by 2 (\# of ovaries/flower) for the computation of overall percentage of natural fruit-set. To compare percentage of fruit-set and number of seeds per mature follicle between natural pollination and other pollination treatments, three flowers on the umbel of each sampled stem were used, and one flower was tagged every other day after the first flower bud opened. After umbels were no longer attractive to pollinators, all sampled umbels were bagged with $15.4 \mathrm{~cm} \times 20.3 \mathrm{~cm}$ [ 6 in $\times 8$ in] handmade pollination bags made of white nylon mesh to prevent destruction of developing follicles by phytophagous insects. The overall percentage of natural fruit-set was computed by the following formula: 
$\%$ natural fruit-set $=$

Total \# of fruits

Total \# of flowers $\times$

\# of ovaries per flower

Because Asclepias has two ovaries per flower, the percentage of natural fruit-set, therefore, was actually calculated as follows:

$\%$ natural fruit-set in Asclepias $=$

Total \# of fruits

Total \# of flowers $\times 2$

Natural fruit-set indicates an overall percentage of fruits produced in nature as the result of open pollinations, but it does not indicate the total number of flowers pollinated or successfully fertilized. After flowers are visited by insect vectors, a successful fertilization may be detected by rapid expansion of the ovary and by recurving of the pedicel and an increase in its diameter. Developing follicles were closely monitored until they were mature, and size of aborted follicles was measured.

Supplemental pollination was performed to determine whether there is an increase in follicle production or in number of seeds per follicle after adding a cross pollinium into a stigmatic chamber. Five to 15 umbels, each from different plants, were sampled from the ALP site within each of the three blooming periods in 1998, and three flowers per umbel were used. One 2-day-old flower on each umbel was selected every other day after the first flower opened, and a 2-dayold pollinium collected from another plant some distance away was inserted into a single chamber. With curve-tipped pollination forceps, pollinia were carefully removed by hooking the tip of the forceps on the groove of the corpusculum. After pollinia were removed from flowers, they were placed onto a dry paper towel in a petri dish and were allowed to dry for several minutes to permit the 90 degree change in orientation of the translator arms.
Insertions with the convex edge of pollinia toward the stigmatic surface were performed by using curve-tipped pollination forceps with the assistance of binocular headglasses $(3.5 \times$ magnification $)$. To ensure that pollen tubes entered the same ovary on each flower, a cross pollinium was inserted into the stigmatic chamber adjacent to one on the same side of the furrow and into which a pollinium had been inserted by a pollinator. The sepals on both sides of the slit where a cross pollinium was inserted were marked with a black permanent marker. After insertions were performed, individual flowers were tagged but not bagged before follicles developed. Once follicles began to develop, they were bagged and then closely monitored until follicles matured. Later, mature follicles that developed on the side with the marked sepals were individually bagged with wax paper bags to prevent seed dispersal after dehiscence.

Intrapopulation and interpopulation cross-pollinations were performed at both the ALP and BSP sites in 1998 to compare the level of fruit-set within and between populations. Thirty plants, each with a single stem composed of a compound umbel, were sampled from each population. Fifteen plants were used for intrapopulation cross-pollination, and another fifteen were used for interpopulation cross-pollination. For interpopulation cross treatments, pollinia were transferred between the two populations. Umbels on sampled plants were bagged with $15.4 \mathrm{~cm} \times 20.3 \mathrm{~cm} \mathrm{[6}$ in $\times$ 8 in] hand-made pollination bags of white nylon mesh and tagged while flowers were still in bud, to prevent visits from insects. Plants that died, due to predation or pathogens after insertions, were removed from the analysis. Three flowers per stem were used for the analysis. Two pollinia were separately inserted into the first and the fourth or the second and the fifth stigmatic chambers in order to ensure that both ovaries had an equal chance to be 
fertilized. I collected 2-day-old pollinia and inserted them, with the convex edge toward the stigmatic surface, into stigmatic chambers of 1- or 2-day-old flowers on different plants. One flower on each umbel was manipulated every other day. All treated flowers were tagged, and umbels were covered again as soon as insertions had been done. The percent fruit-set from intraand interpopulation cross-pollination was computed separately by using the following formula:

$$
\begin{gathered}
\% \text { fruit-set from } \\
\text { cross-pollination }
\end{gathered}=\frac{\text { Total \# of fruits }}{\begin{array}{c}
\text { Total \# of ovaries used } \\
\text { for cross-pollination }
\end{array}}
$$

Again, developing follicles were closely monitored, and number of fruits aborted was recorded until mature follicles were harvested.

The level of self-compatibility was estimated by performing self-pollinations at ALP in 1997. Fifteen umbels, each from different plants, were sampled, bagged, and tagged prior to flower opening. Three 1- or 2-day-old flowers on each umbel (one flower per umbellet) were selected, and two 2-day-old pollinia from different flowers on the same umbel were separately inserted into the first and the fourth or the second and the fifth stigmatic chambers of a flower. The level of self-compatibility was computed by using the following formula:

$$
\begin{aligned}
& \% \text { fruit-set from } \\
& \text { self-pollination }=
\end{aligned} \quad \frac{\text { Total \# of fruits }}{\begin{array}{c}
\text { Total \# of ovaries used } \\
\text { for self-pollination }
\end{array}}
$$

Flowers with the inserted pollinia were bagged again and monitored until flowers withered. If follicles developed, they were closely monitored until mature, then harvested and their seeds counted.

\section{Flowering Phenology and Insect Visitation}

Twenty-five randomly selected plots $(2 \mathrm{~m} \times 2 \mathrm{~m})$ were established at the ALP site prior to the beginning of the flowering season in 1998 to study flowering phenology. The number of open flowers on all umbels within each plot was counted once a week in the late afternoon. Individual inflorescences or umbels sampled in 1997 and 1998 for open pollination treatment were used to determine the number of flowers per inflorescence and flowering span. Flowering of each inflorescence was monitored from the first flower opening to senescence of the last flower.

Insect visitations were observed once a week during the flowering season in 1998. Also, a camcorder was used to record insect activities in the field. Three unmanipulated plots $(2 \mathrm{~m} \times 2 \mathrm{~m})$ with abundant open flowers were selected for each observation day. Each plot was observed $10 \mathrm{~min}$ per $\mathrm{h}$ from morning (0800) until evening (2000). The number of visitations to all three selected plots was totaled as the number of visitations for the entire day, and proportion of visits per insect taxon was also calculated. During the flowering season, 24 umbellets composed of 356 flowers were collected, and the numbers of pollinia inserted and removed were scored to detect pollinator activities.

Throughout the entire flowering season, insects were collected in the adjacent area to count the number of pollinia on the body parts of different insect genera and to determine which were potential pollinators. To maintain the size of insect populations, insects with no pollinaria carried were recorded and released. On the other hand, some insects with pollinaria were killed, and the parts of the body on which pollinaria were carried were observed under a dissecting microscope. 


\section{Insertions of Pollinia}

To estimate whether seed-set resulting from a successful cross-pollination is directly related to the orientation of the inserted pollinium, four different types of pollinium insertion were performed at the ALP site in 1998: vertical insertion with the convex edge towards the stigmatic surface (VTS), vertical insertion with the convex edge opposite the stigmatic surface (VOS), horizontal insertion with the convex edge towards the ground (HTG), and horizontal insertion with the convex edge opposite the ground (HOG). For each type of insertion, 25 umbels, each from a different plant, were sampled, tagged, and bagged with $15.4 \mathrm{~cm} \times$ $20.3 \mathrm{~cm}$ [6 in $\times 8$ in] pollination bags prior to flower opening. All cross pollinia were collected from 2-day-old flowers, and one cross pollinium was inserted into the stigmatic chamber of a 1 - or 2-day-old flower. Three flowers per umbel were manipulated. Two umbels for each type of insertion were used every other day. After pollinia were inserted, umbels were rebagged to prevent further pollination. All developing follicles were monitored until mature follicles were harvested, and the number of seeds per follicle was counted.

\section{Statistical Analyses}

The significance level for all statistical tests performed in this study was $\alpha=0.05$. To compare percent fruit-set resulting from open-pollination with fruit set from supplemental pollination and to compare fruit-set from intrapopulation crosses with that from interpopulation crosses, a test for equality of two percentages (Sokal and Rohlf 1969) was used. Natural fruit-set between the 1997 and 1998 flowering seasons was also tested by equality of two percentages. A two tailed $t$-test (Zar 1984) was used to analyze whether a significant difference occurs between seed-set resulting from open-pollination with that from supplemental, hand cross-, and hand selfpollinations.

\section{RESULTS AND DISCUSSION}

\section{The Structure of the Gynostegium}

Like the anatomical structure of the gynoecium of several Asclepias species previously described (Woodson 1947, 1954; Wyatt and Broyles 1994), the gynoecium of A. viridis is composed of two separate, superior ovaries united by their styles and fused with the stamens to form the gynostegium (Figure 5). Five concave surfaces, generally known as stigmatic surfaces, are located within the stigmatic chambers. In this study, however, the results indicate that the stigmatic surfaces are not those five concave surfaces, nor are they located in each of the five stigmatic chambers. In fact, the pair of anther wings extending from two adjacent anthers are partially fused with the stigmatic head at the base of the stigmatic chambers (Figure 6). At the base of the stigmatic chambers, the filaments join together into a tube surrounding the ovaries and styles (Walters and Keil 1996; Figure 7).

My anatomical data provide evidence to argue that the stigmatic chambers are actually part of the androecium, not the gynoecium. In addition, numerous cuboidal cells line up in the concave surface of the stigmatic chamber to form a rather smooth wall (Figure 8) and function as nectaries. Therefore, the stigmatic chamber may position the inserted pollinium and either promote or inhibit germination of pollen tubes depending on the concentration of nectar (Kevan et al. 1989; Sage et al. 1990). In fact, the stigmatic surfaces appear to consist of numerous elongate epidermal cells located at the base of the gynostegium where the two styles unite (Figure 9). Furthermore, after pollen tubes germinate in the stigmatic chamber, they penetrate through the nectary tissue beneath the stigmatic chamber and then grow through a cylinder-like space between the stigmatic chambers and the stigmatic surfaces 
(Figure 10) to reach the stigmatic surfaces from which they grow into one of the styles.

My findings are similar to A. T.

Brongniart's illustration in 1832 of the reproductive structures of a typical milkweed flower (Sundell 1984). After combining the above findings with the orientation of the furrow on top of the gynostegium in relation to the position of the two styles, not only does the furrow divide the five chambers into two groups, but it also separates the two styles along the point of fusion of the two styles.

Nevertheless, one of the stigmatic chambers could still possibly transmit pollen tubes into both styles (Figure 11). This discovery may explain why pollen tubes occasionally cross over at the point of fusion of the two styles (Sparrow and Pearson 1948; Morse 1993; Wyatt and Broyles 1994) to produce twin follicles after a pollinium is inserted into that particular chamber. According to my anatomical data, two adjacent chambers $(1,2)$ on one side of the furrow can transmit pollen tubes to one ovary, and two other adjacent chambers $(4,5)$ on the other side of the furrow can transmit pollen tubes to the other ovary (Figure 12). However, chamber 3 , in line with the furrow, can potentially transmit pollen tubes to either or both ovaries to produce twin follicles (see Figure 12). In Morse's (1993) study of A. syriaca, $29 \%$ of all hand-pollinations produce mature follicles, and $1.86 \%$ of mature follicles were twin follicles.

However, he did not specify which chamber was assigned to perform the insertions. If the chambers were randomly assigned, the probability of selecting the particular chamber is 0.2. Then it can be predicted that the maximum percent of twinning would be $5.8 \%$ in his study. In contrast, an increase in the number of twin follicles produced from hand pollination with a single insertion could be anticipated if the chamber in line with the furrow is specifically assigned. To avoid "crossingover" and to enhance the probability that all pollen tubes of a single pollinium enter only one of the ovaries, the particular stigmatic chamber assigned for an insertion is an important consideration.

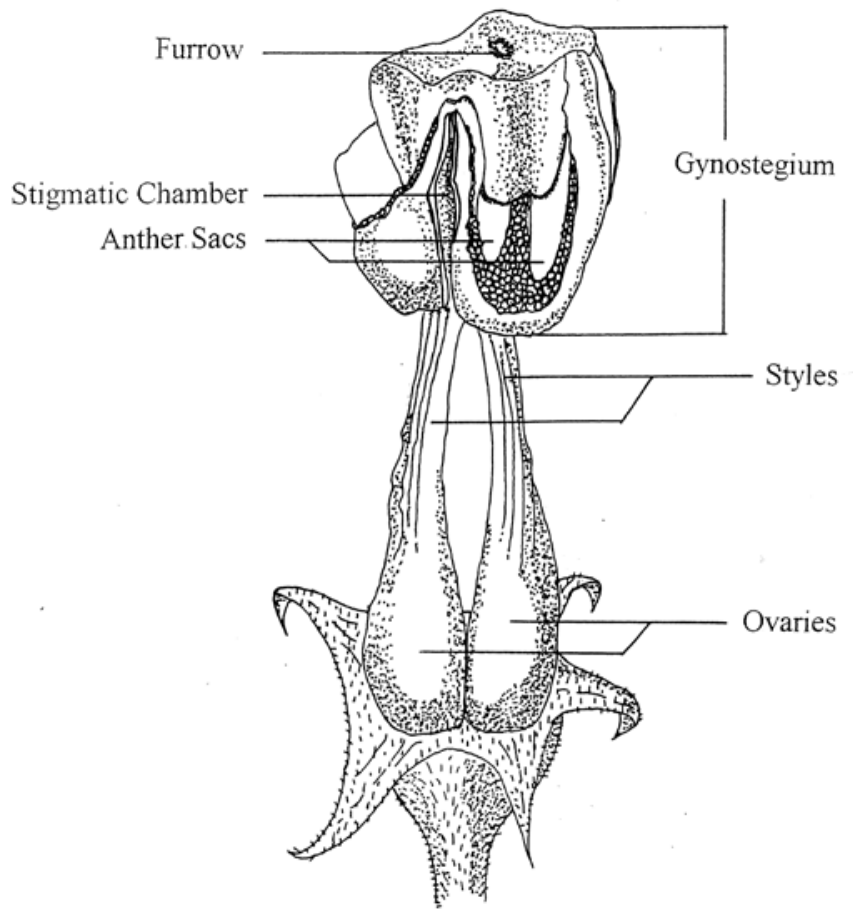

Figure 5 The reproductive structures of Asclepias viridis 


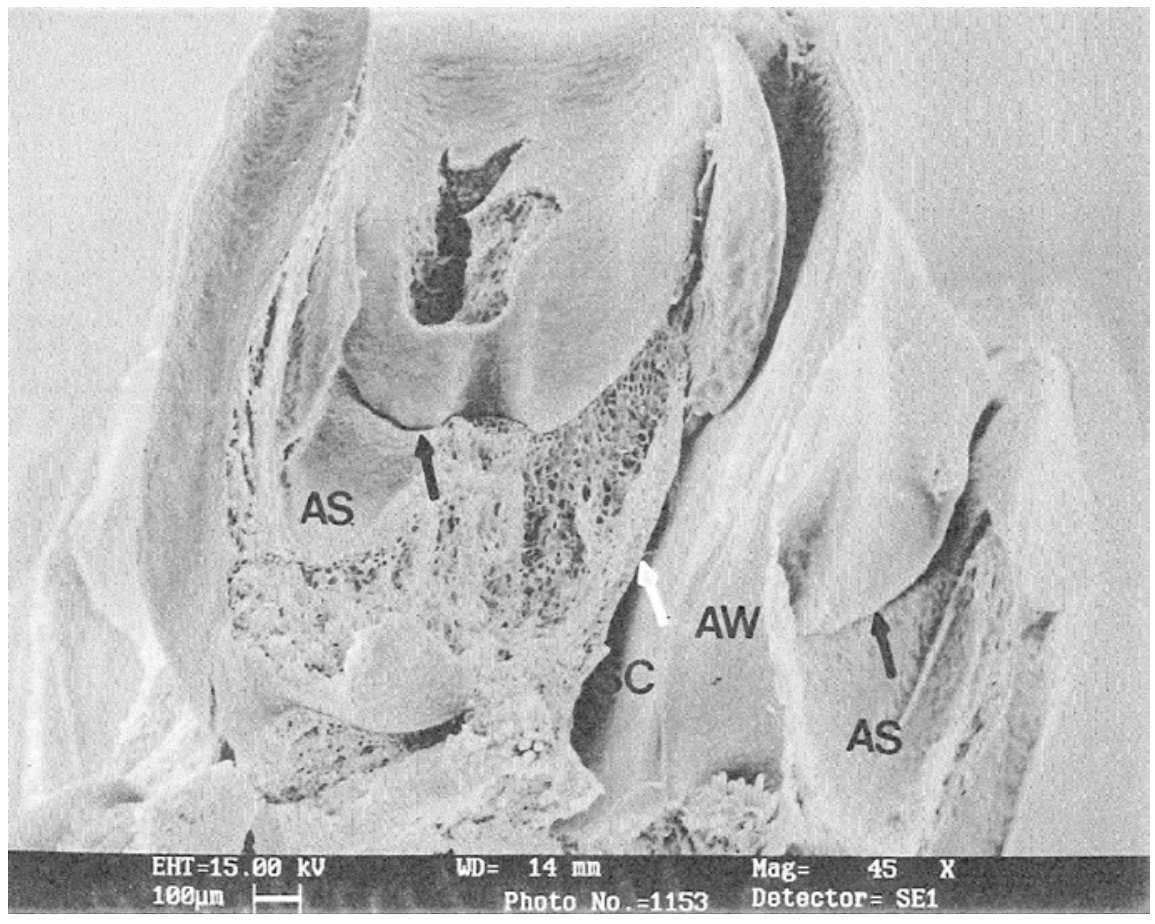

Figure 6 The relative position of the androecium and the gynoecium of the gynostegium of Asclepias viridis. The black arrows indicate the fusion between androecium and gynoecium and the white arrow indicates one of the anther wings (AW) removed to expose the stigmatic chamber (SC) to be part of the androecium. (Abbreviation: AS, anther sacs)

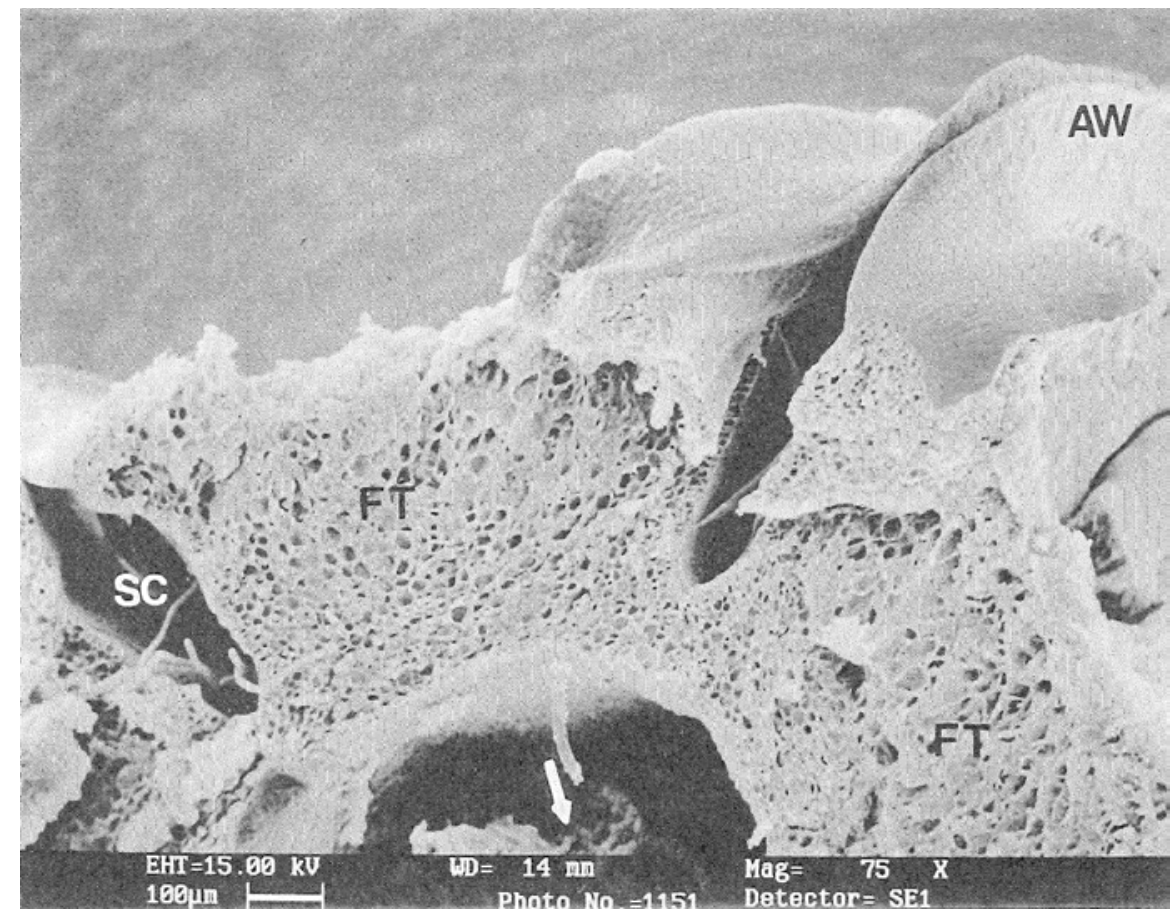

Figure 7 Filament tissue (FT) at the base of the androecium of the flower of Asclepias viridis. One of the styles is indicated by a white arrow. (Abbreviations: SC, stigmatic chamber; AW, anther wing) 


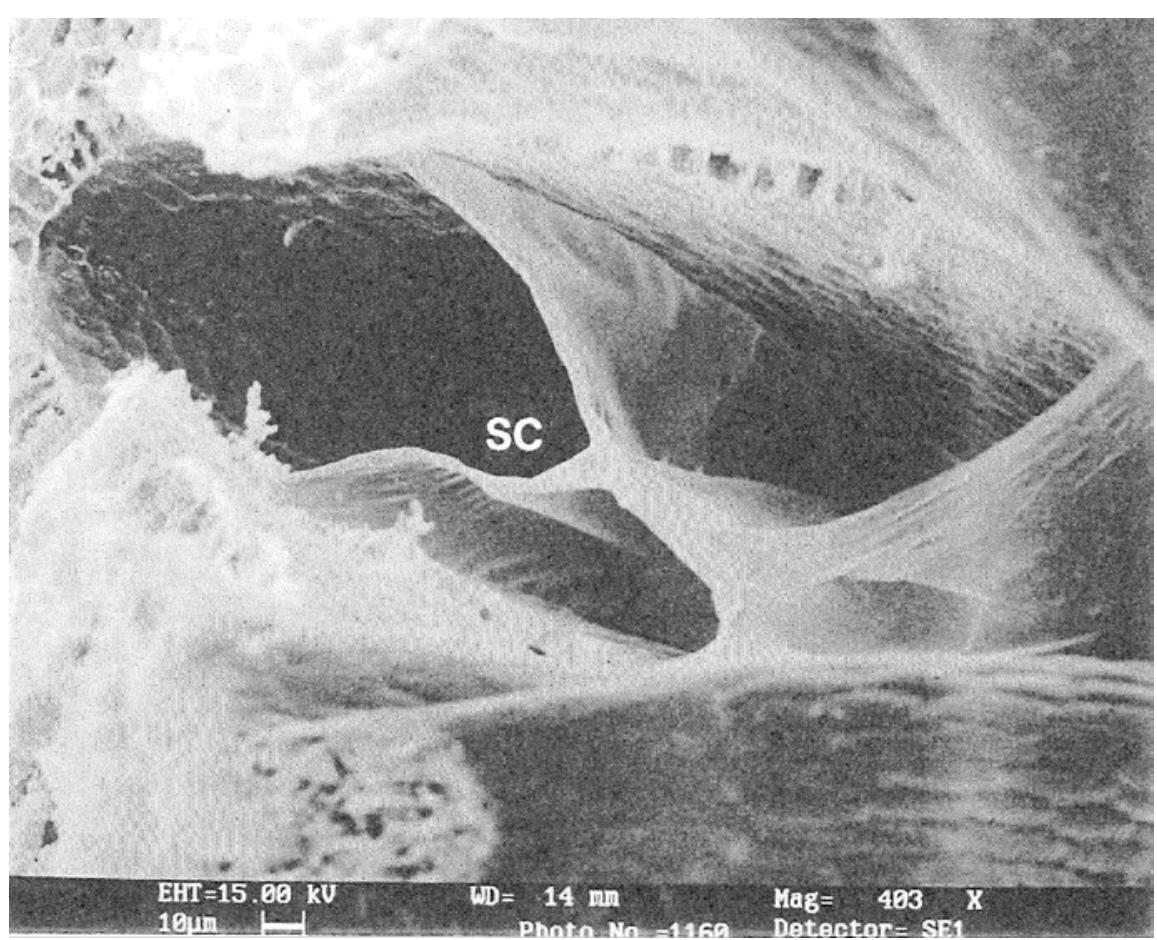

Figure 8 The stigmatic chamber (SC) and the nectaries of Asclepias viridis composed of numerous cuboidal cells

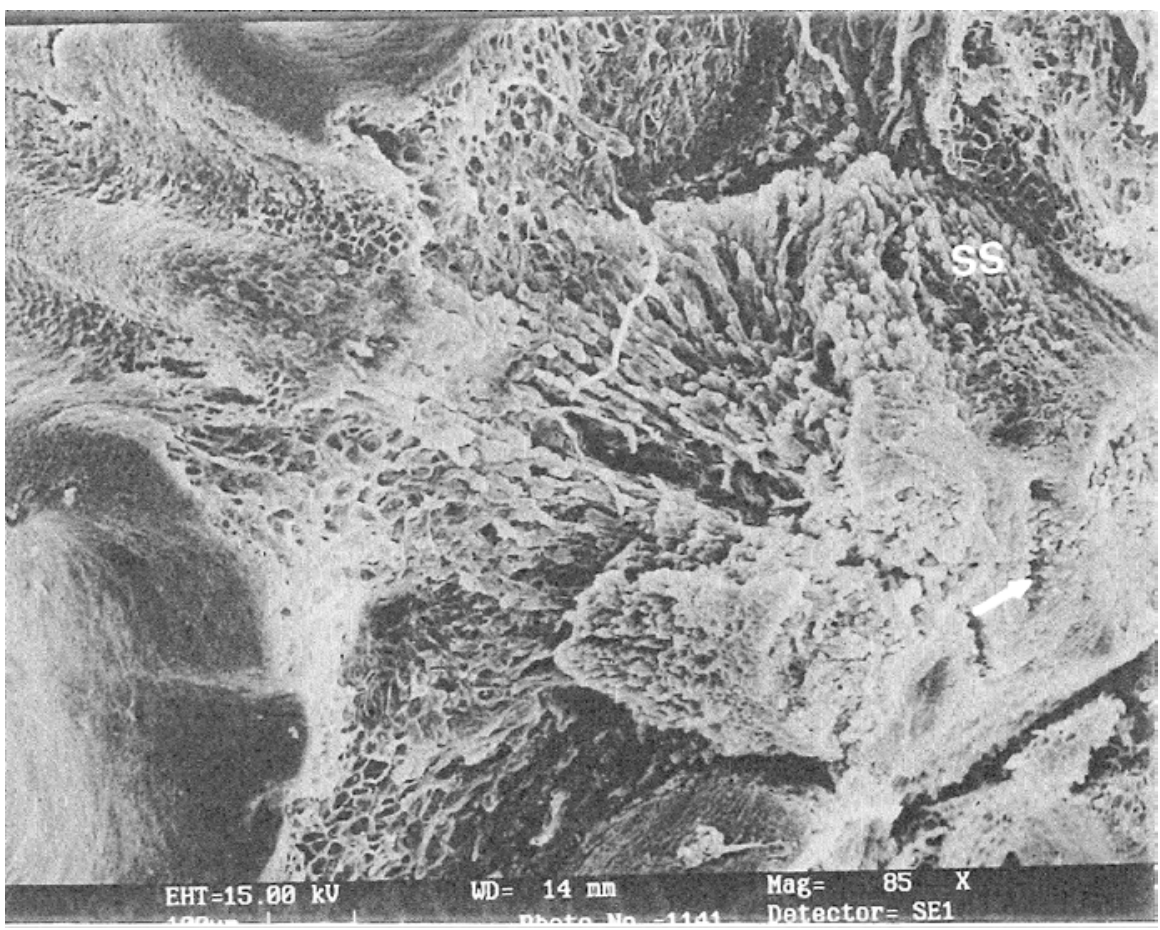

Figure 9 The stigmatic surface (SS) of flowers of Asclepias viridis at the base of the gynostegium. The white arrow in the lower right indicates the area of fusion of two styles. 


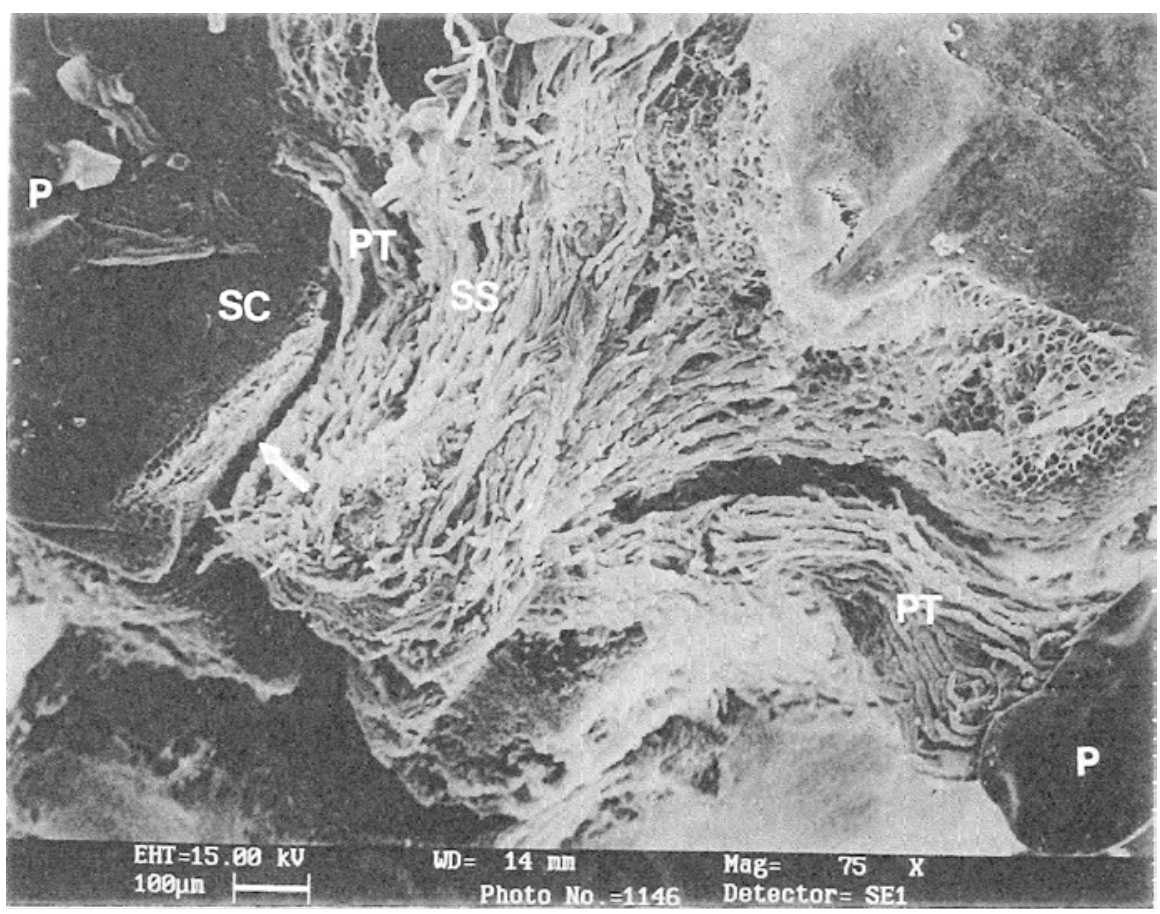

Figure 10 Pollen tubes (PT) of Asclepias viridis grow into the stigmatic surface (SS) after pollen grains germinate in the stigmatic chambers (SC). The cylinder-like space between the stigmatic chamber and the stigmatic surface is indicated by a white arrow. (Abbreviation: $\mathrm{P}$, pollinium)

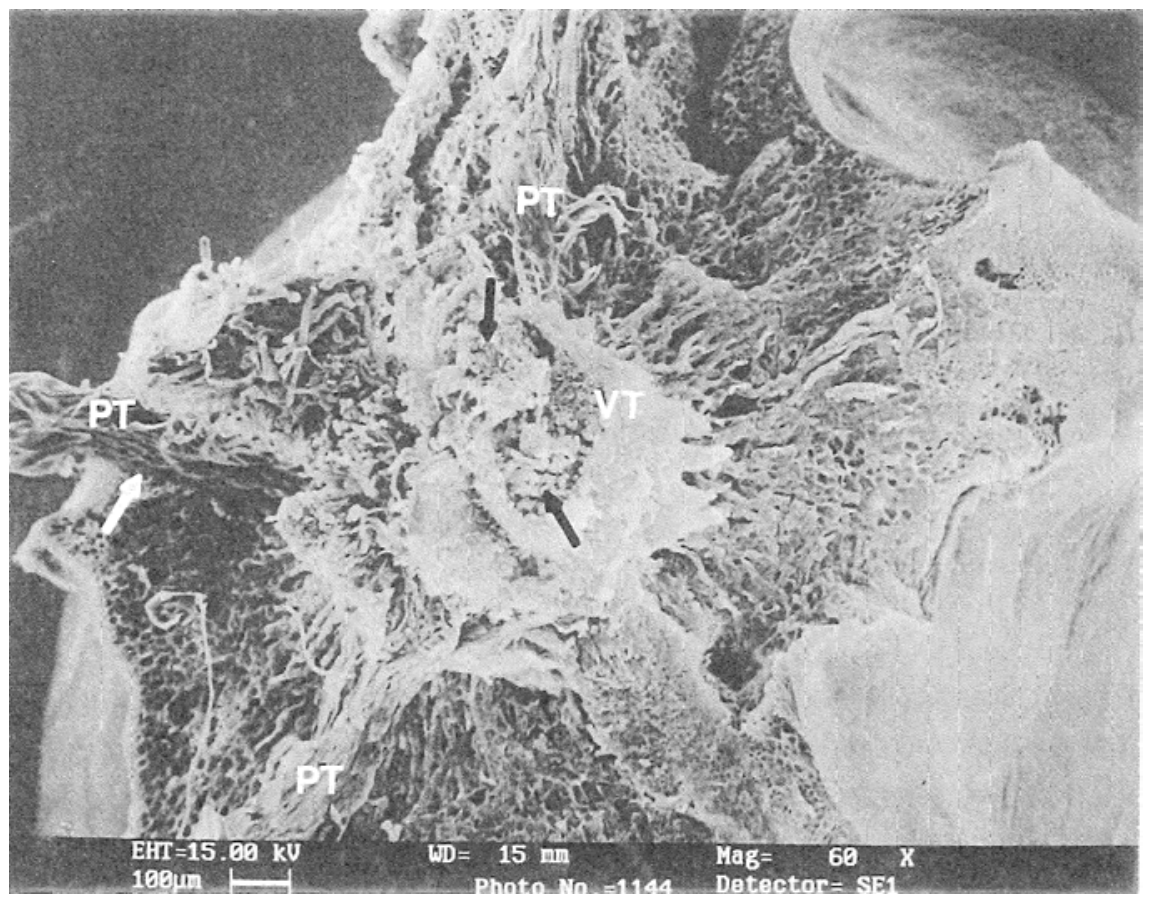

Figure 11 A view from the reverse side of the gynostegium of Asclepias viridis to show the relationship between the five stigmatic chambers and two styles. One of the chambers, indicated by a white arrow, can potentially transmit pollen tubes (PT) into both styles indicated by black arrows. (Abbreviation: VT, vascular tissue) 


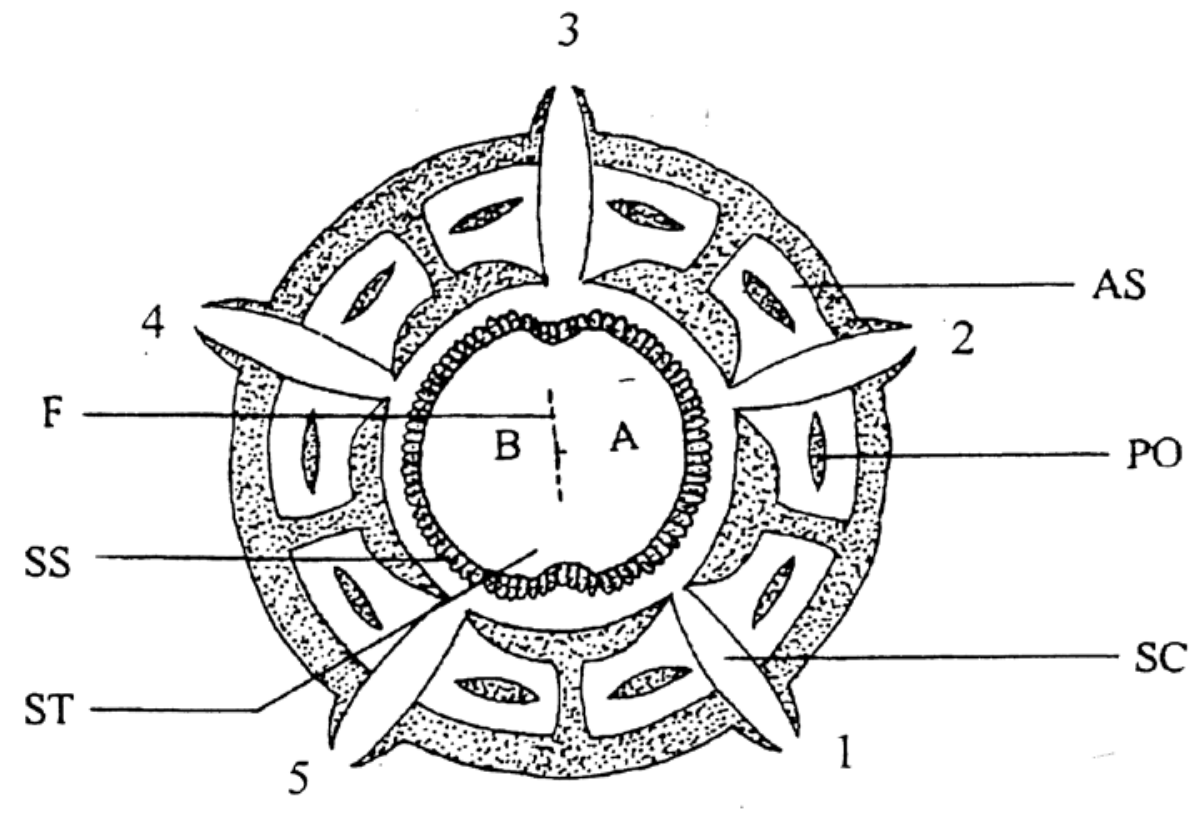

Figure 12 A transverse section of the gynostegium of Asclepias viridis shows the location of the stigmatic chambers (SC) relative to the styles (ST), the stigmatic surface (SS), and the furrow (F). Chambers 1 and 2 lead pollen tubes into style A, and chambers 4 and 5 lead pollen tubes into style B. Chamber 3 can possibly lead pollen tubes into styles A, B, or both ("cross-over"). (Abbreviations: AS, anther sac; P, pollinium)

\section{Breeding System}

Natural Fruit-Set, Predation, and Follicle Abortion

The overall percentage of natural fruitset in the ALP population was $1.87 \%$ in 1997 and $1.39 \%$ in 1998 (Table 1). There was no statistically significant difference $(t=$ $1.786, P>0.05)$ in natural fruit-set between the two seasons. Similar results were also found on those tagged flowers for open pollination (see Table 1). A low level of young follicle production in my study may suggest that either a high level of self-pollen is deposited by pollinators, or insufficient pollination occurs in this population. After 24 umbellets composed of a total 356 flowers of different ages were examined for removal and insertion of pollinia (Figure 13), 87\% of the pollinia, based on the lack of corpuscula on flowers, had been removed $(9.2 \pm 2.2$ pollinia per flower; range $0-10$ ), and $82 \%$ of sampled flowers had no corpuscula left. Ninety-one percent of flowers had been pollinated, and $58 \%$ of the slits were filled by at least one pollinium $(2.9 \pm 1.6$ pollinia per flower; range $0-8)$ inserted by pollinators (see Figure 13). The natural insertion rate could be higher than these results indicate because some flowers on those umbels had not withered and could still attract pollinators. The results, however, suggest that pollinator limitation does not occur in this population because one cross pollinium is sufficient to initiate follicle production. Presumably, an insufficient number of pollen tubes germinating from compatible pollen and/or excessive self-pollination may be major causes of the failure of young follicles to be produced. In addition, my data show a 


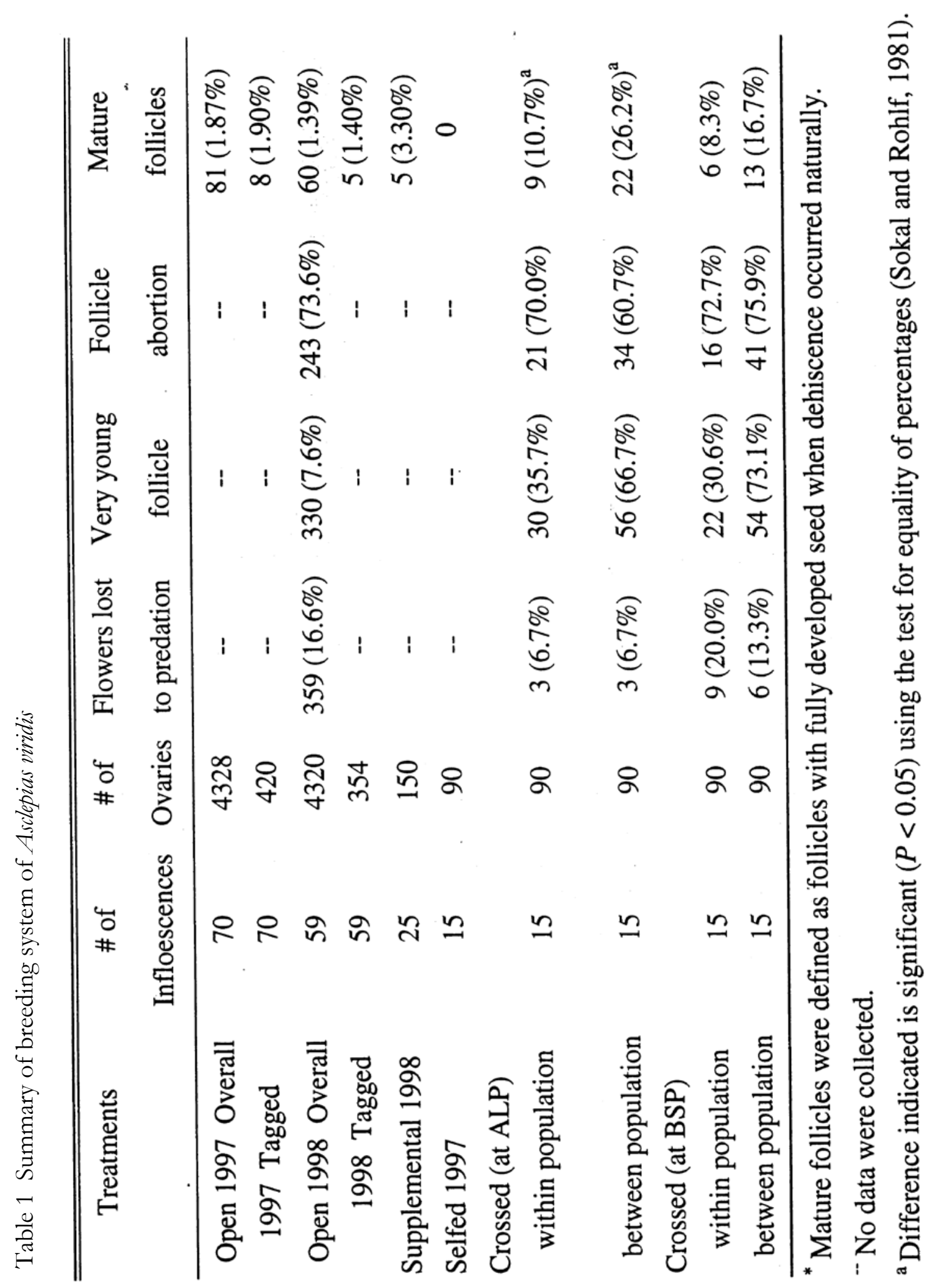




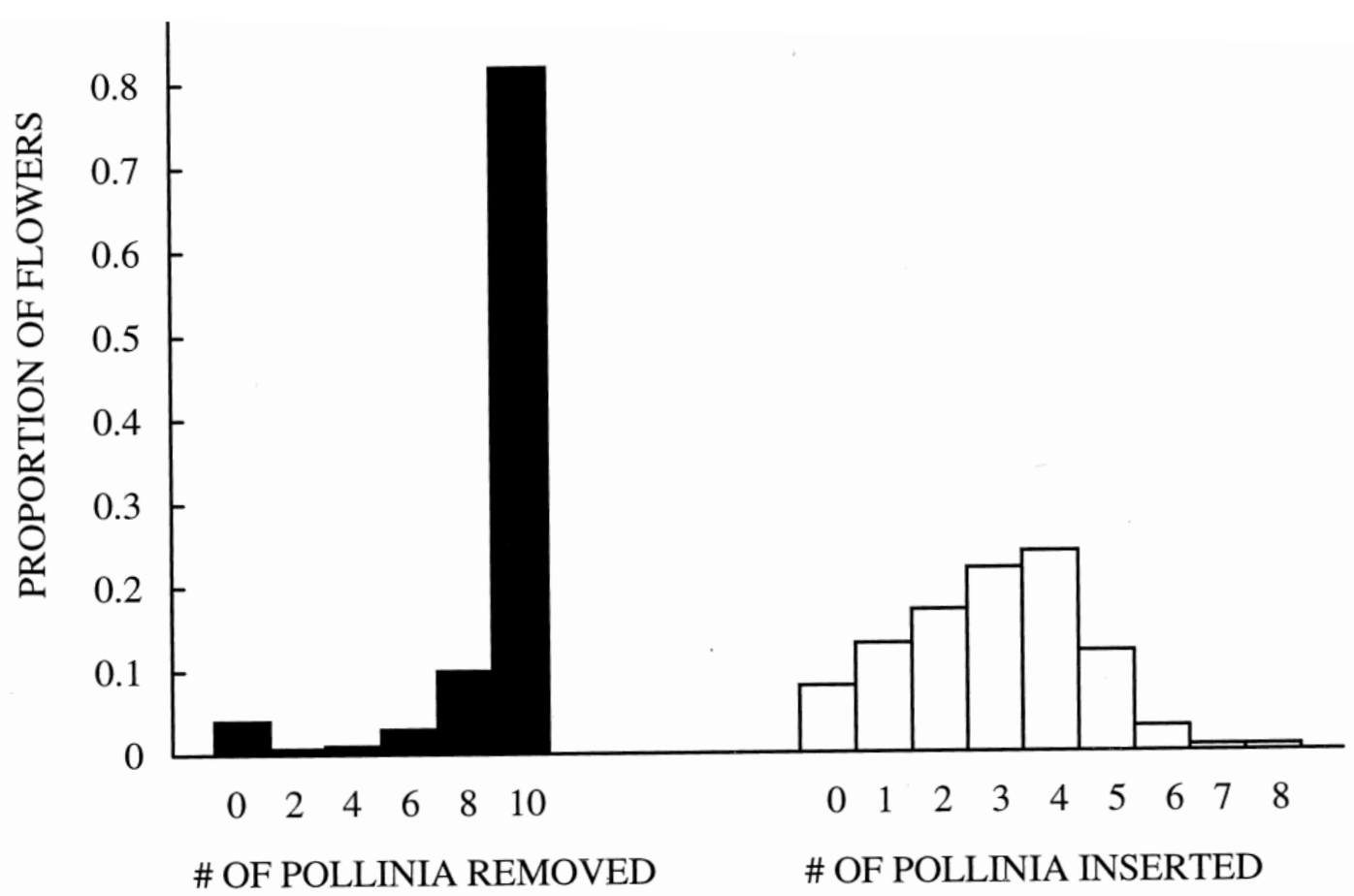

Figure 13 The proportion of flowers with different numbers of pollinia removed and inserted at the UCO Lake Arcadia Research Area. Removals of pollinia (0-10) were based on the numbers of missing corpuscula. Numbers of insertions from 0 to 8 (from left to right on insertions histogram) were based on the number of pollinia found in the stigmatic chambers. In some cases, more than two pollinia were counted in a single slit. A maximum of 8 inserted pollinia were scored. $(\mathrm{N}=356)$

rather high level (about 17\%) of flower and young follicle (about $8 \%$ of developing follicles) predation in this population. Particularly towards the end of the flowering season, phytophagous insects such as katydids (Tettigoniidae) severely attacked flowers, and over $27 \%$ of sampled flowers were consumed. Therefore, flower consumption by insects may also affect follicle production in natural populations.

In addition to low initiation of young follicles, the low level of fruit-set may result from a high level of follicle abortion in Asclepias populations. In my study, $73.6 \%$ of follicles from open pollination aborted at different sizes after initiated follicles became measurable (see Table 1). Abortion may be the major cause of failure of initiated follicles to mature, and two hypotheses, resource limitation and self-incompatibility, are often proposed to explain low fruit-set or low follicle survivorship (Shannon and Wyatt 1986; Wyatt and Broyles 1994).

The follicle survivorship curve for $A$. viridis (Figure 14) in my study shows that most mortality occurred before the follicles reached a length of about $4 \mathrm{~cm}$ (stage "d"). The effects of seed predators (Oncopeltus sp. and Lygaeus sp.) became detectable at later stages (stage " $d$ " to maturity) of development. Particularly, clusters of Lygaeus sp. nymphs were often seen on mature follicles. However, they became common only later in the flowering season, so it is unlikely that they could be the primary cause of the decline of survivorship. 
Therefore, I believe that mortality during the early stages of follicle development was caused by follicle abortion. Moreover, in my results from self-pollination and observations in the field, even though the pedicel of a self-pollinated flower showed a slight thickening in diameter, it never recurved over $90^{\circ}$ from its original position on the peduncle before abscission occurred between the pedicel and peduncle. A crosspollinated flower, in contrast, could be detected by a striking thickening and rapid recurving of the pedicel so that it became parallel with the peduncle and by continued development of the young follicle.

Nevertheless, most developing follicles aborted before they were mature $(2.14 \mathrm{~cm} \pm$ $1.18 \mathrm{~cm}$; mean $\pm \mathrm{SD}$; Figure 15). Unlike the self-pollinated young follicles, the aborted young follicles from cross-pollination generally remained on the stem with a "woody" pedicel. Flowers produced and cross-pollinated early in the flowering season seemed likely to develop into mature follicles successfully. On the other hand, follicles produced from the later crosspollinated flowers on the same umbel generally aborted along the way before they reached maturity. This observation may suggest that competition for resources among developing follicles on a single plant of $A$. viridis, like in other studies (Willson and Price 1977; Queller 1985), may occur in my study population.

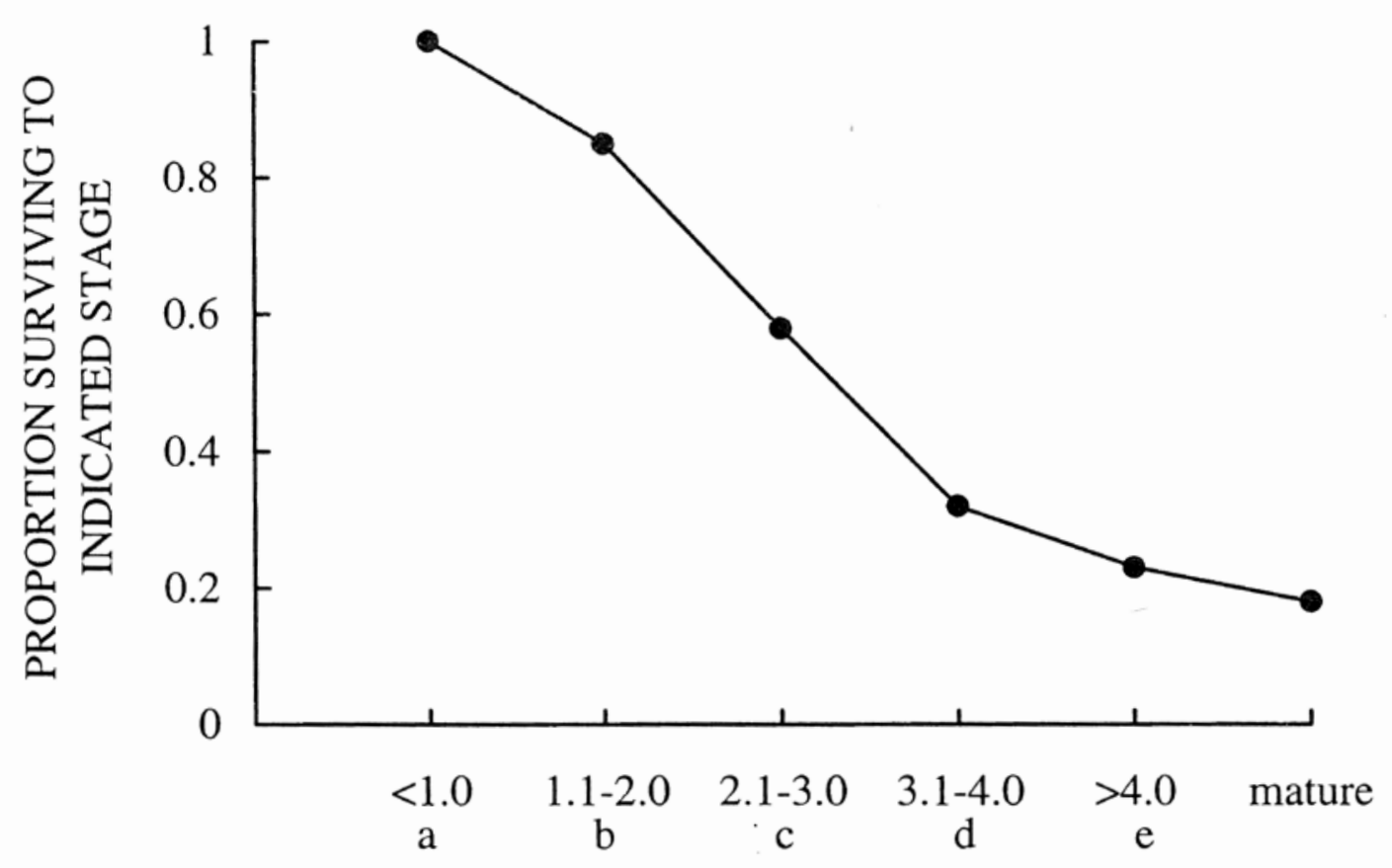

STAGE OF FOLLICLE DEVELOPMENT (cm)

Figure 14 Survivorship curve of Asclepias viridis follicles at the UCO Lake Arcadia Research Area in 1998. The curve was based on aborted follicles which possibly resulted from cross-pollination in nature. $(\mathrm{N}=330)$ 


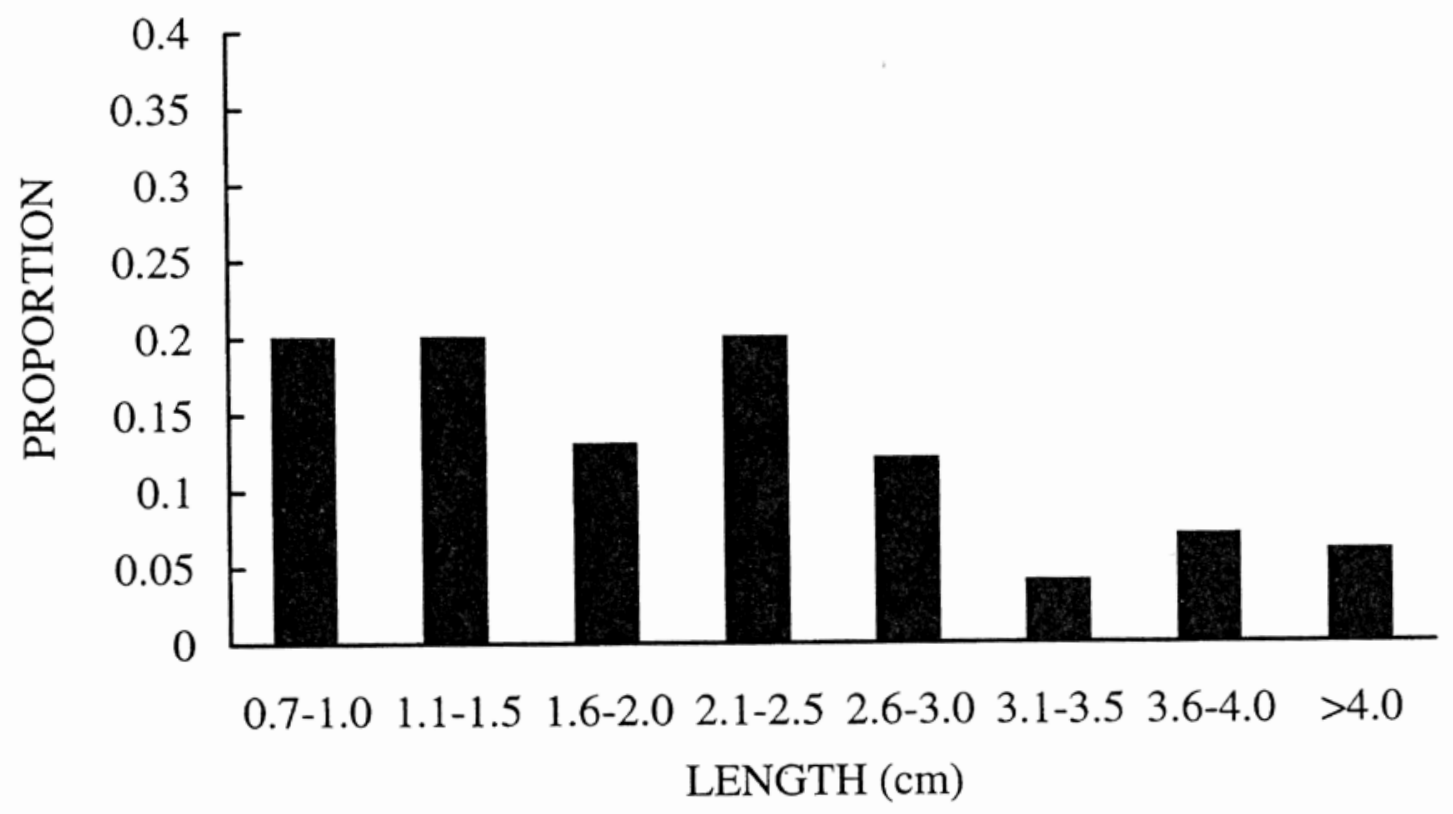

Figure 15 Proportion of aborted follicles of various lengths from open pollination of Asclepias viridis at the UCO Lake Arcadia Research Area in 1998 (mean $\pm \mathrm{SD}=2.14 \mathrm{~cm} \pm 1.18 \mathrm{~cm}$; $\mathrm{N}=138$ )

Table 2 Number of seeds in follicles resulting from pollination treatments and open pollination of Asclepias viridis during the 1998 flowering season

\begin{tabular}{lcccc}
\hline \multicolumn{1}{c}{ Treatments } & $\begin{array}{c}\text { \# of } \\
\text { Ovaries }\end{array}$ & $\begin{array}{c}\text { \# of } \\
\text { Mature follicles }\end{array}$ & $\begin{array}{c}\text { \# Seeds } \\
\text { per follicle } \\
\text { mean } \pm \text { SD }\end{array}$ & $t(P$ value $)$ \\
\hline Open & 354 & $5(1.4 \%)$ & $103.2 \pm 33.5$ & \\
Supplemental & 150 & $5(3.3 \%)$ & $121.4 \pm 18.5$ & $1.06(P>0.2) \mathrm{ns}$ \\
Crossed (ALP) & & & & \\
within & 90 & $9(10.7 \%)$ & $74.1 \pm 21.8$ & $3.05(P<0.01)^{*}$ \\
between & 90 & $22(26.2 \%)$ & $97.4 \pm 18.3$ & \\
Crossed (BSP) & & & & \\
within & 90 & $6(8.3 \%)$ & $73.7 \pm 8.5$ & $2.42(\mathrm{P}<0.05)^{*}$ \\
between & 90 & $13(16.7 \%)$ & $98.4 \pm 24.1$ & \\
\hline
\end{tabular}

(ns = not significant, ${ }^{*}=$ significant at 0.05 level) 


\section{Supplemental Pollination}

Five out of 150 ovaries treated for supplemental pollination developed into mature follicles. The percent fruit-set $(3.3 \%)$ for supplemental pollination was over twice that for open pollination for 1998 (see Table 1). However, this difference was not statistically significant $(t=1.315, P>0.1)$. Moreover, although the number of apparently viable seeds per follicle was higher for supplemental pollination (121.4 \pm 18.5) than for open pollination (103.2 \pm 33.5; Table 2), there was not a statistically significant difference either $(t=1.062, P>$ $0.2)$. These results show that supplemental pollination of $A$. viridis is unable to increase fruit- and seed-set. The reason is perhaps pollen competition between self- and crosspollen (Broyles and Wyatt 1993) in which self-pollen interferes with cross-pollen tubes and prevents them from penetrating the styles (Kahn and Morse 1991). As one properly inserted cross-pollinium is sufficient to initiate a young follicle which may reach maturity, subsequent pollinations in an Asclepias population seem only to play a minor role. Many studies (Ellstrand 1984; Schoen 1985; Brown et al. 1986) have shown that subsequent pollinations are successful in some species that disperse pollen grains individually, as evidence of multiple paternity was found among seeds within a fruit. However, multiple paternity occurs neither in $A$. exaltata (Broyles and Wyatt 1990) nor $A$. syriaca (Gold and Shore 1995) and may not occur among seeds within follicles of other Asclepias species.

\section{Hand Cross-Pollination}

At the ALP site, only nine follicles reached maturity from intrapopulation cross-pollinations; whereas, 22 mature follicles were harvested from interpopulation cross-pollinations. Six follicles were harvested from intrapopulation crosses and 13 follicles from interpopulation crosses from the BSP site. Follicle production at the ALP site was significantly different between the two treatments $(t=2.65, P<0.05$; see Table 1$)$. Nevertheless, three developing follicles produced from the successful intrapopulation crosses were removed from the analysis due to seed predation. If these data were not excluded, follicle production would not be statistically different between the treatments at the ALP site $(t=1.94$, $P>0.05)$. At the BSP site, follicle production between intra- and interpopulation crosses was not statistically different $(t=1.58, P>0.05$; see Table 1$)$. However, follicles of interpopulation crosses produced higher seed-set than did follicles of intrapopulation crosses for both the ALP $(t=3.05, P<0.05)$ and the BSP site $(t=2.42, P<0.05$; see Table 2$)$.

My data from the ALP site are similar to Kephart's findings (1981) in which interpopulation cross-pollination yielded significantly higher fruit-set for both $A$. incarnata and $A$. verticillata but in contrast with Wyatt's findings (1976) for $A$. tuberosa. The "optimal outcrossing distance" has long been explained as the intermediate distances at which matings between individuals should produce the greatest fitness benefits (Waser and Price 1983; Kearns and Inouye 1993). It has been studied for some species (Price and Waser 1979; Sobrevila 1988) but has not yet been found for Asclepias. Kephart (1981) did not state the distance between the sampled populations in her study, but she explained that the different results for intra- and interpopulation crosspollination was because of the lower similarity of $\mathrm{S}$ alleles between the individuals used for interpopulation crosses than for intrapopulation crosses. On the other hand, Wyatt (1976) suggested that crosses between highly dissimilar individuals from $A$. tuberosa populations $390 \mathrm{~km}$ apart might cause outbreeding depression leading to lower fruit-set. My results for both hand crosspollination treatments at both sites suggest that neither an outbreeding depression nor an apparent inbreeding depression occurs 
between the two populations to lower the number of follicles produced from either intra- and interpopulation crosses. Nevertheless, results of seed production indicate that matings between individuals within these two isolated populations may affect seed-set in milkweed follicles. As suggested by Broyles and Wyatt (1991), mating between genetically similar individuals usually produced fruits with fewer viable seeds. Interestingly, $40 \%$ $(20 / 50)$ of follicles produced from both hand cross-pollination treatments at both study sites were "twins." The percent of the twin follicles produced from double insertions is higher than in other studies (Sage, Broyles, and Wyatt 1990).

\section{Self-Pollination}

None of 90 self-pollinated ovaries successfully produced mature follicles at the ALP site in 1997 (see Table 1). This demonstrates that strong selfincompatibility occurs in $A$. viridis. In my study, 64 self-fertilized ovaries $(71.1 \%)$ showed slight enlargement, pubescence, and usually remained green for 10-12 days, but no further development showed before they aborted. On the other hand, the rest of the self-pollinated ovaries that did not show these phenomena usually only remained for several days before abscission occurred. Recently, Wyatt and Broyles (1994) suggested that an ovarian selfincompatibility system, in which pollen tubes are rejected before or after penetrating ovules, typically occurs in Asclepias.

Similarly, Kahn and Morse (1991) described a post fertilization incompatibility system, in which the embryo does not divide after selfpollenated tubes penetrate ovules in their A. syriaca population.

\section{Flowering Phenology}

In 1998, A. viridis began flowering in early May and reached its flowering peak in late May (Figure 16). Flowering densities declined from the third week (late May) after the beginning of flowering, and no flowers were observed in experimental plots in the seventh week. In general, the flowering period of $A$. viridis in my study area was seven weeks, even though a few open flowers were occasionally seen in late June. The mean number of flowers produced per inflorescence was 34.1 (SD = 10.2, range 14-69, $N=115$; Figure 17). The mean flowering span (time from first flower opening to senescence of the last flower) per inflorescence was 10.6 d (SD = 0.99, range $7-13, \mathrm{~N}=15)$.

\section{Flower Visitors and Insect Visitation Flower Visitors}

Flowers of $A$. viridis were visited by at least 20 families of the orders Hymenoptera, Lepidoptera, Coleoptera, and Hemiptera. Occasional visits were recorded from other orders as well (Table 3). Overall, Hymenoptera are apparently the most frequent vectors, as $67 \%$ of captured Hymenoptera were carrying pollinaria (Table 4). This included $87 \%$ of captured Scoliidae (wasps), 98\% of Apidae (bumblebees; Bombus spp.), and 68\% of Anthophoridae (carpenter and digger bees). Among hymenopterans, Bombus spp. are the most active pollinators of $A$. viridis, based on the numbers of pollinaria carried (Figure 18). Of scored corpuscula, $94 \%$ were attached to their front legs (Figure 19). Bumblebees carried as many as 186 corpuscula on their front legs, with the corpusculum channel of one pollinarium hooked to a seta, and the other pollinaria linked together with the corpusculum channel of one pollinarium hooked to a translator arm of another pollinarium (Figure 20). During field observations, I noted that after bumblebees landed on flowers, they frequently brushed against the gynostegium rapidly with their front legs. This behavior might help to position their bodies on flowers while they take nectar, and it might enhance their efficiency in removing and inserting pollinia. In contrast, 
other hymenopterans, such as large carpenter bees (Xylocopa; Anthophoridae) and wasps, generally either sat on flowers or gently manipulated flowers for nectar. Consequently, their behavior may result in less contact with the gynostegium and result in removal of fewer pollinaria from flowers.

Even though halictid bees (Halictidae) and paper wasps (Vespidae) carry pollinaria of other Asclepias species (Macior 1965; Fishbein and Venable 1996), they did not carry pollinaria of $A$. viridis. Most of the time, halictid bees landed on one of the hoods to consume nectar and rarely contacted the gynostegium. Presumably, their small body size relative to the flower size and their behavior at the flowers restricted contact with the gynostegium. On the other hand, paper wasps landed just momentarily; this behavior and the reduced setae of their appendages may be factors contributing to the absence of pollinaria on their bodies.

Lepidoptera rarely carried the pollinaria of $A$. viridis in my study population, unlike observations for other Asclepias species (Willson et al. 1979; Fishbein and Venable
1996). Only one pollinarium, which was attached to a front leg, was found on the 43 captured individuals in the family Lycaenidae (see Table 4). No pollinaria were carried by 57 common skippers (Hesperiidae) captured in the field. Monarchs (Danaidae) and sulfur butterflies (Pieridae) were occasionally observed during the flowering season, but no visitations were recorded at plots.

One out of 109 captured soldier beetles (Cantharidae) carried a pollinarium on a mouth part. Soldier beetles visited flowers and chewed on the flower parts, mostly hoods, and fed on nectar. Due to the lack of sufficient field data, whether soldier beetles are able to function as pollinators in this population is still unknown. Families Lygaeidae and Pentatomidae of Hemiptera presumably only fed on vascular sap or nectar, due to their behavior at the flowers, and carried no pollinaria (see Table 4). Although flies (Diptera) also occasionally visited flowers of $A$. viridis, they were not collected. Therefore, their role in this plant population is uncertain.

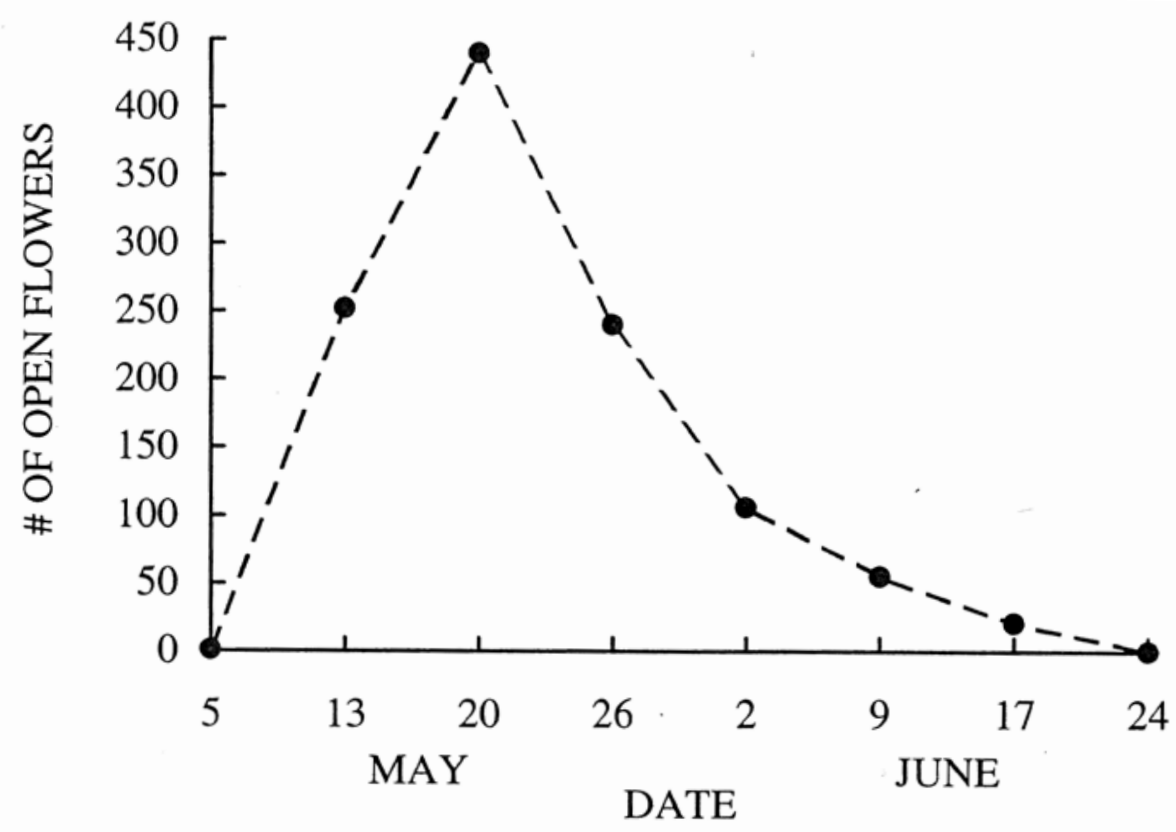

Figure 16 Flowering phenology of Asclepias viridis at the UCO Lake Arcadia Research Area in 1998. The flowering peak occurred in late May. 


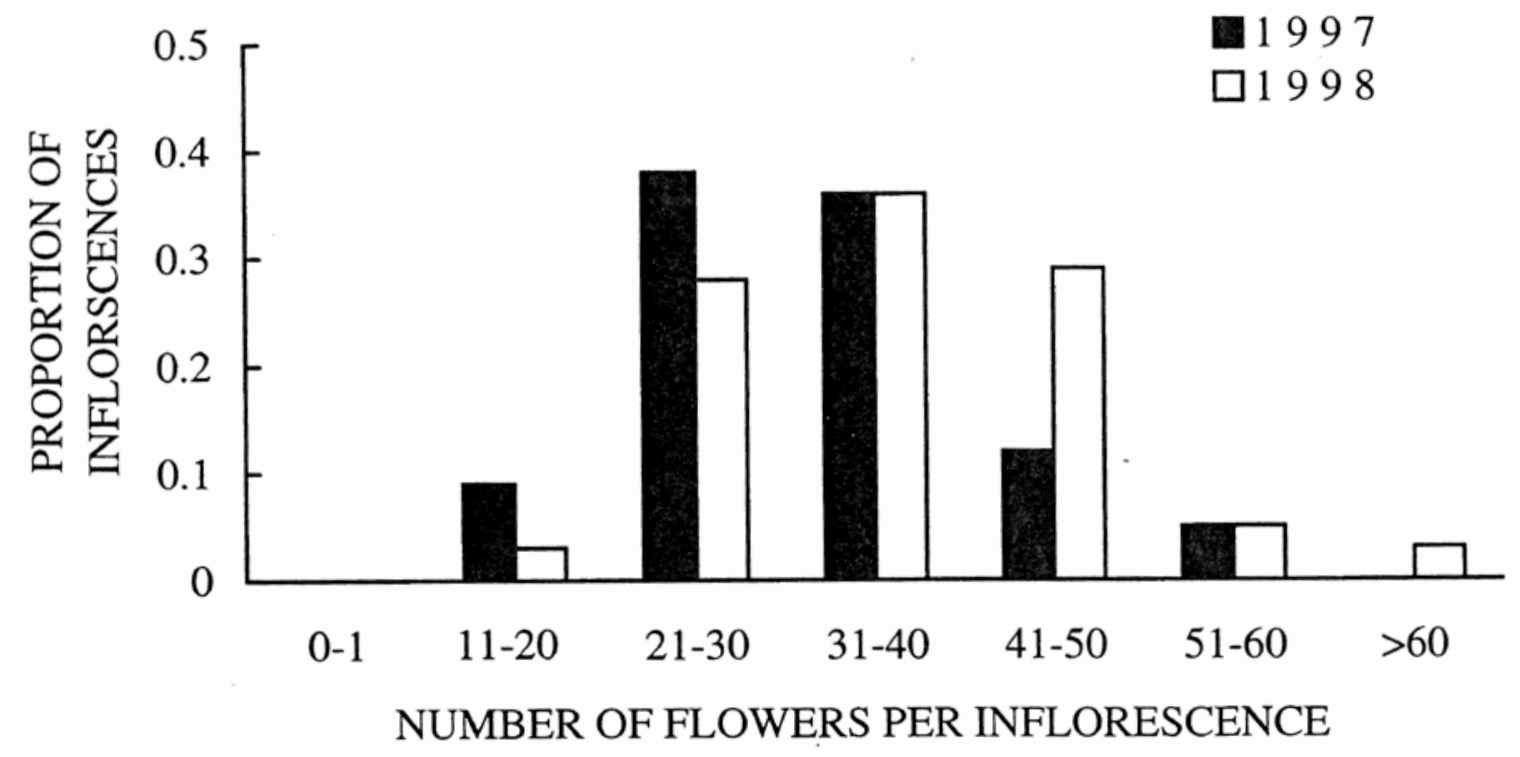

Figure 17 Proportion of Asclepias viridis inflorescences with different numbers of flowers at the UCO Lake Arcadia Research Area during the 1997 and 1998 seasons

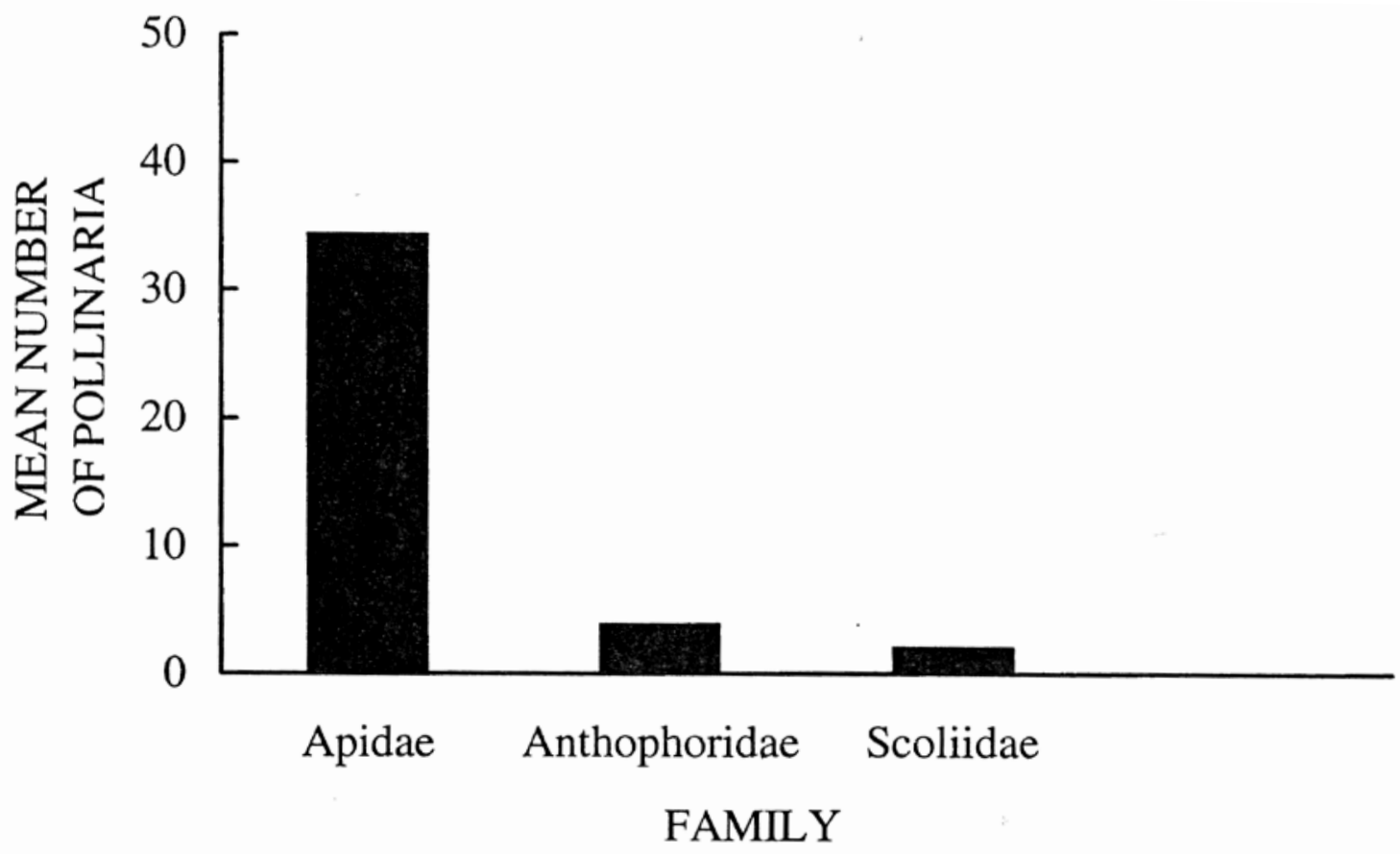

Figure 18 Average number of pollinaria scored from collected hymenopteran visitors to flowers of Asclepias viridis at the UCO Lake Arcadia Research Area in the 1997 and 1998 flowering seasons 
Table 3 Orders and families of flower visitors to Asclepias viridis at the UCO Lake Arcadia Research Area during the 1997 and 1998 flowering seasons. Question mark (?) indicates that dipteran visitors were rarely observed landing on the flowers but were not collected.

\begin{tabular}{|c|c|c|}
\hline ORDER & FAMILY & YEAR \\
\hline Orthoptera & Tettigoniidae & $1997 ; 1998$ \\
\hline \multirow[t]{3}{*}{ Hemiptera } & Lygaeidae & $1997 ; 1998$ \\
\hline & Pentatomidae & 1997 \\
\hline & others & 1997 \\
\hline Diptera & $?$ & 1998 \\
\hline \multirow[t]{8}{*}{ Coleoptera } & Cantharidae & $1997 ; 1998$ \\
\hline & Lampyridae & 1997 \\
\hline & Coccinellidae & $1997 ; 1998$ \\
\hline & Meloidae & 1997 \\
\hline & Chrysomelidae & $1997 ; 1998$ \\
\hline & Cerambycidae & $1997 ; 1998$ \\
\hline & Curculionidae & $1997 ; 1998$ \\
\hline & others & $1997 ; 1998$ \\
\hline \multirow[t]{4}{*}{ Lepidoptera } & Pieridae & 1998 \\
\hline & Danaidae & 1997 \\
\hline & Hesperiidae & $1997 ; 1998$ \\
\hline & Lycaenidae & $1997 ; 1998$ \\
\hline \multirow[t]{6}{*}{ Hymenoptera } & Pompilidae & 1998 \\
\hline & Scoliidae & $1997 ; 1998$ \\
\hline & Vespidae & $1997 ; 1998$ \\
\hline & Halictidae & $1997 ; 1998$ \\
\hline & Apidae & $1997 ; 1998$ \\
\hline & Anthophoridae & $1997 ; 1998$ \\
\hline
\end{tabular}


Table 4 Numbers of captured visitors from different families, and of those, numbers carrying at least one pollinarium. Data were collected during the flowering season of Asclepias viridis at the UCO Lake Arcadia Research Area in 1997 and 1998.

\begin{tabular}{|c|c|c|c|}
\hline Order & Family & $\begin{array}{l}\text { \# insects } \\
\text { captured }\end{array}$ & $\begin{array}{c}\text { \# of insects carrying } \\
\text { at least one } \\
\text { pollinarium }\end{array}$ \\
\hline Orthoptera & Tettigoniidae & 9 & 0 \\
\hline \multirow[t]{3}{*}{ Hemiptera } & Lygaeidae & 139 & 0 \\
\hline & Pentatomidae & 23 & 0 \\
\hline & others & 39 & 0 \\
\hline \multirow[t]{8}{*}{ Coleoptera } & Cantharidae & 109 & 1 \\
\hline & Lampyridae & 9 & 0 \\
\hline & Coccinellidae & 21 & 0 \\
\hline & Meloidae & 15 & 0 \\
\hline & Chrysomelidae & 22 & 0 \\
\hline & Cerambycidae & 11 & 0 \\
\hline & Curculionidae & 16 & 0 \\
\hline & others & 39 & 0 \\
\hline \multirow[t]{4}{*}{ Lepidoptera } & Pieridae & 5 & 0 \\
\hline & Danaidae & 4 & 0 \\
\hline & Hesperiidae & 57 & 0 \\
\hline & Lycaenidae & 43 & 1 \\
\hline \multirow[t]{6}{*}{ Hymenoptera } & Pompilidae & 1 & 0 \\
\hline & Scoliidae & 15 & 13 \\
\hline & Vespidae & 11 & 0 \\
\hline & Halictidae & 39 & 0 \\
\hline & Apidae & 97 & 95 \\
\hline & Anthophoridae & 57 & 39 \\
\hline
\end{tabular}




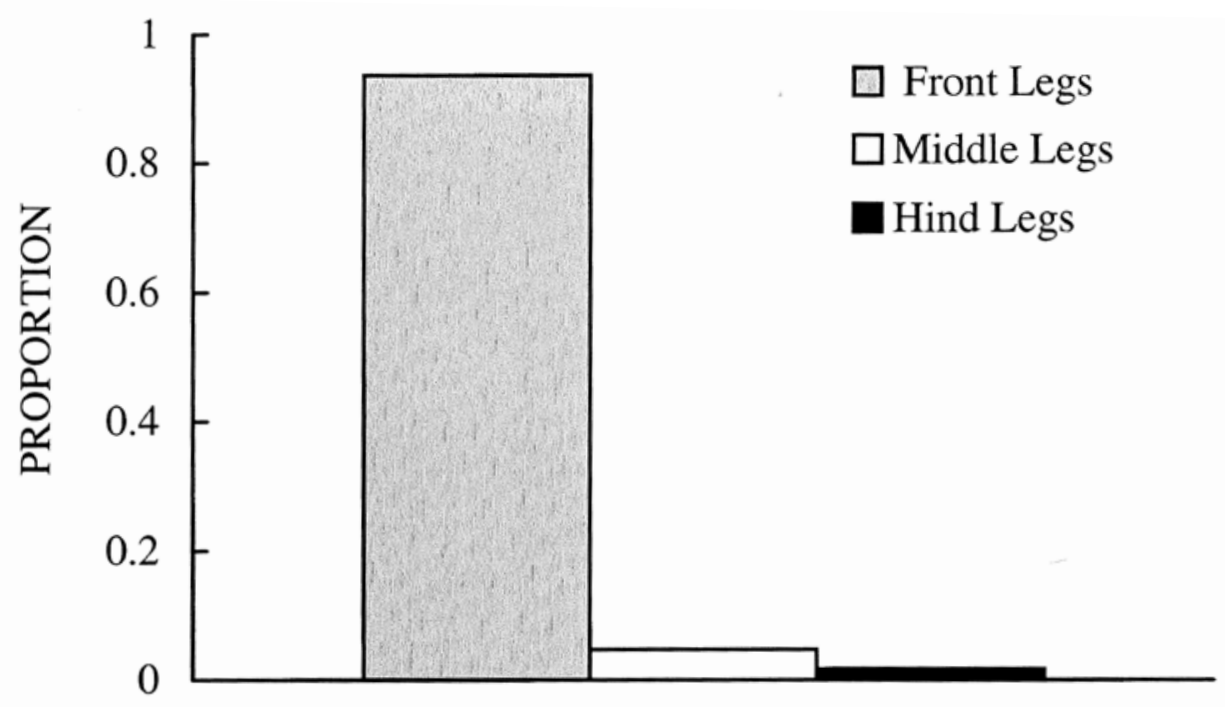

\section{BUMBLEBEE LEGS}

Figure 19 Proportion of pollinaria of Asclepias viridis on front, middle, and hind legs of bumblebees (Bombus spp.) collected at the UCO Lake Arcadia Research Area during the 1997 and 1998 flowering seasons

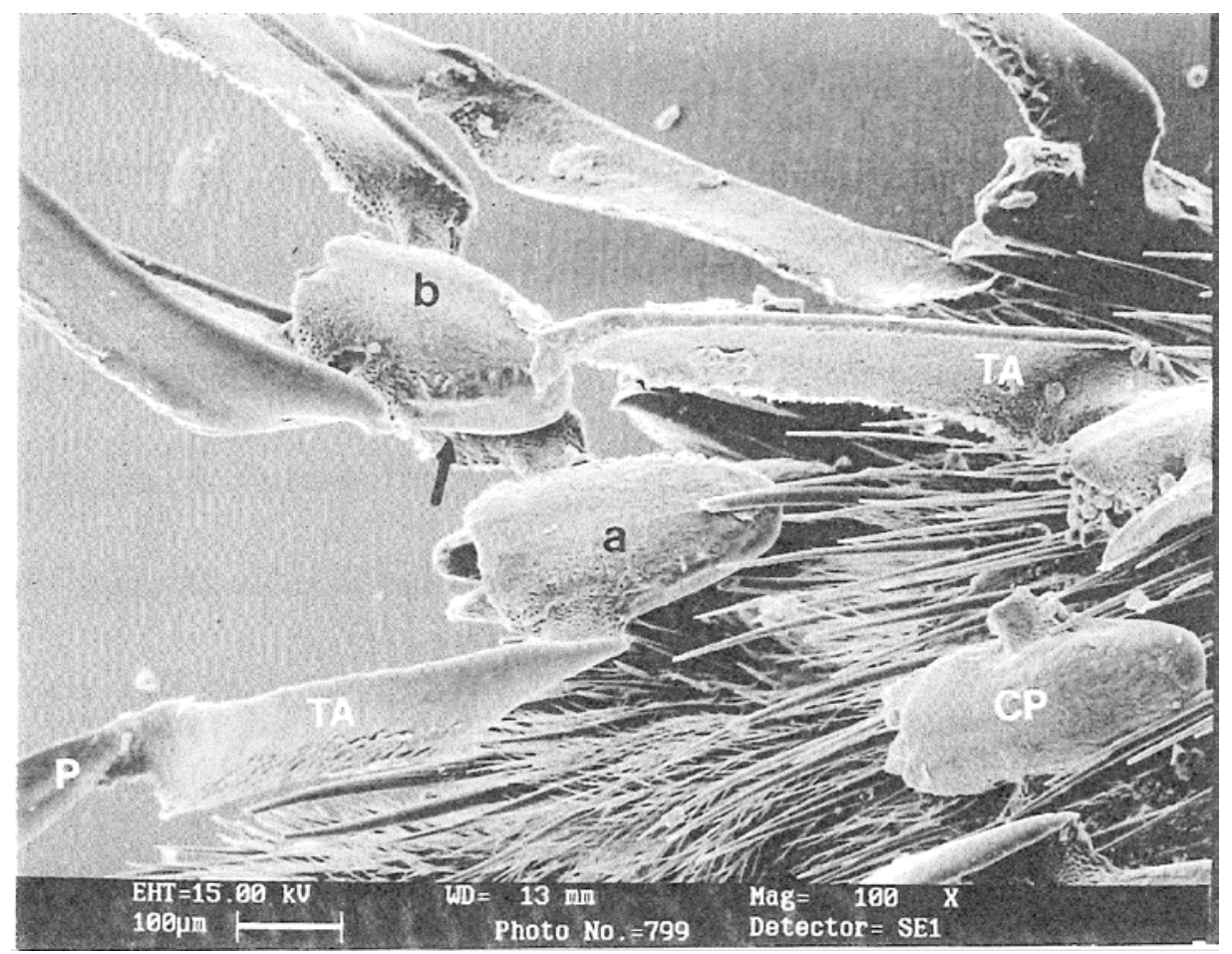

Figure 20 Several pollinaria of Asclepias viridis attached to a leg of a bumblebee (Bombus sp.). In this SEM picture, pollinarium " $a$ " is directly attached on the leg by its corpusculum (CP). On the other hand, pollinarium " $b$ " is attached to pollinarium " $a$ " by clipping its corpusculum onto one of the translator arms (TA) of pollinarium " $a$ ", as indicated by a black arrow. (Abbreviation: P, pollinium) Photograph by D. Elmendorf. 


\section{Insect Visitation}

Hymenoptera accounted for $74 \%$ of overall visitation at the ALP site (Figure 21), of which Scoliidae, Anthophoridae, and Apidae accounted for 98\% (Figure 22). Bombus spp. (Apidae) were the most frequent hymenopteran vectors, accounting for $73 \%$ of hymenopteran visitation and $53 \%$ of overall visitation. In general, hymenopterans visited flowers of $A$. viridis during all daily observation periods during the flowering season (Figure 23). Although bumblebees visited flowers from morning to evening, more visitations were recorded in the mid-afternoon to early evening (1400-2000) rather than in the morning to early afternoon (0800-1400). During the flowering season, carpenter bees were observed for the first three weeks and were rarely observed after the mid-flowering season (Figure 24). On the other hand, visitation by bumblebees to flowers gradually declined towards the midflowering season (mid-May to late-May) and increased towards the latter period of the flowering season (early-June to mid-June). This visitation pattern is perhaps related to flower density, which increased from midMay to late-May and declined from late-May to mid-June. As flower density increased, this could have led to fewer visits per individual plant.

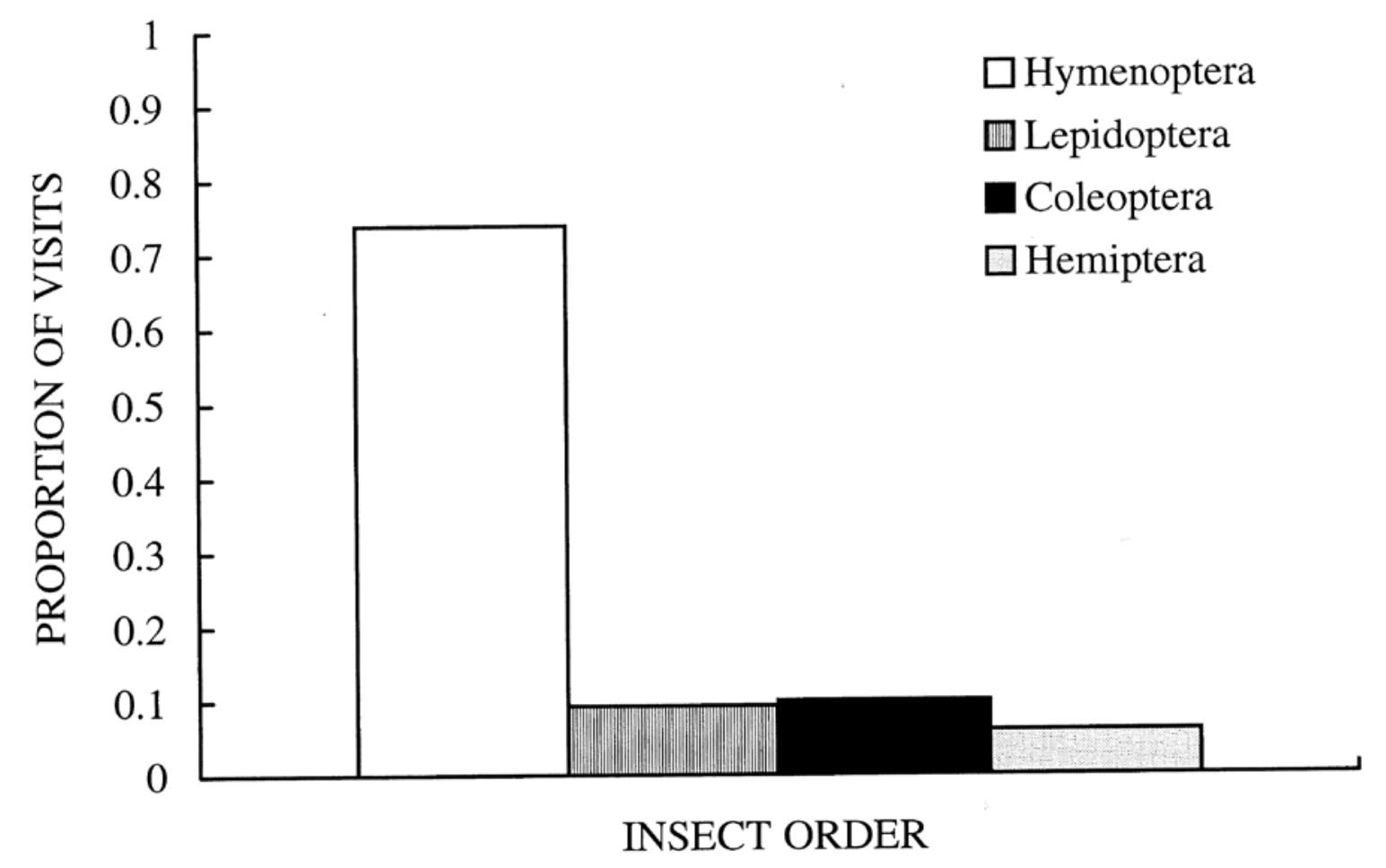

Figure 21 Proportion of visits by insect orders to flowers of Asclepias viridis at the UCO Lake Arcadia Research Area during the 1998 flowering season 


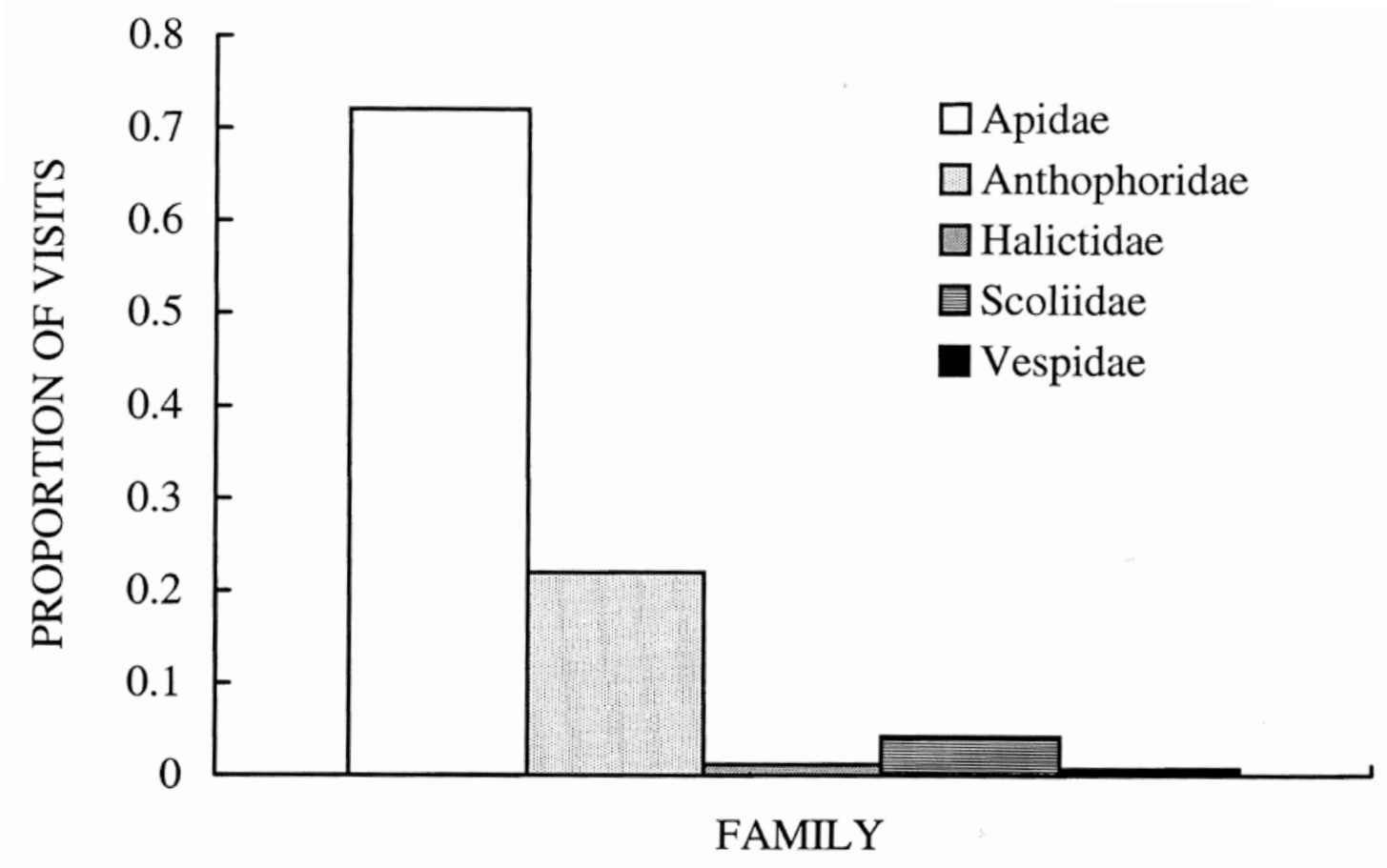

Figure 22 Proportion of visits by hymenopteran families to flowers of Asclepias viridis at the UCO Lake Arcadia Research Area during the 1998 flowering season

\section{Pollinia Insertion}

Eleven mature follicles were harvested from the VTS group (vertical insertion with the convex edge towards the stigmatic surface), and two mature follicles were harvested from the HOG group (horizontal insertion with the convex edge opposite the ground). Neither the VOS group (vertical insertion with the convex edge opposite the stigmatic surface) nor the HTG group (horizontal insertion with the convex edge towards the ground) produced mature follicles (Table 5). A statistical test was not performed due to insufficient data.

Nevertheless, the percentage of mature follicles in the VTS group was apparently higher than in other groups, and pollinia are almost always inserted into the slits by insects in this manner in natural populations. Wyatt (1976) observed over 500 pollinia insertions of $A$. tuberosa, and all pollinia were inserted into the chambers with the convex edge brought into contact with the inner surfaces of the chambers. From my observation of 1035 pollinia insertions of $A$. viridis, almost all of them were inserted in this same manner. It is not surprising to obtain mature follicles from the HOG group. Although this type of insertion (HOG) was rare, a few were observed on flowers of collected umbels with the pollen tubes growing into the stigmatic chambers. However, this type of insertion perhaps occurs accidentally as flowers are visited by insects, such as when breakage occurs between the translator arms and the pollinium before the pollinium is oriented properly into a slit. A microscopic study of some flowers collected with the VOS and HTG types of insertions revealed that most pollen did not germinate, or pollen tubes were exposed outside of the slits and dried out in a few cases. 


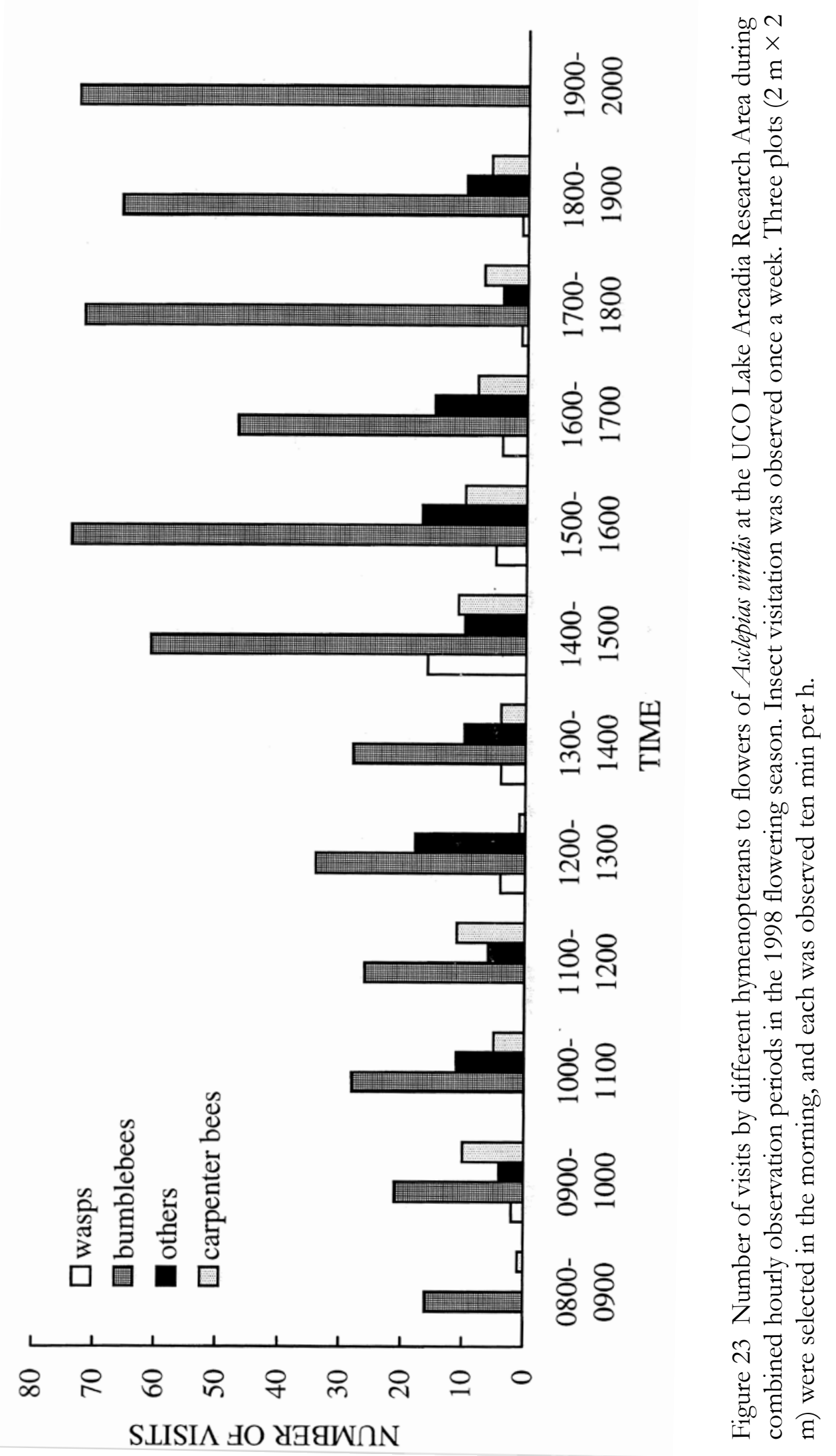




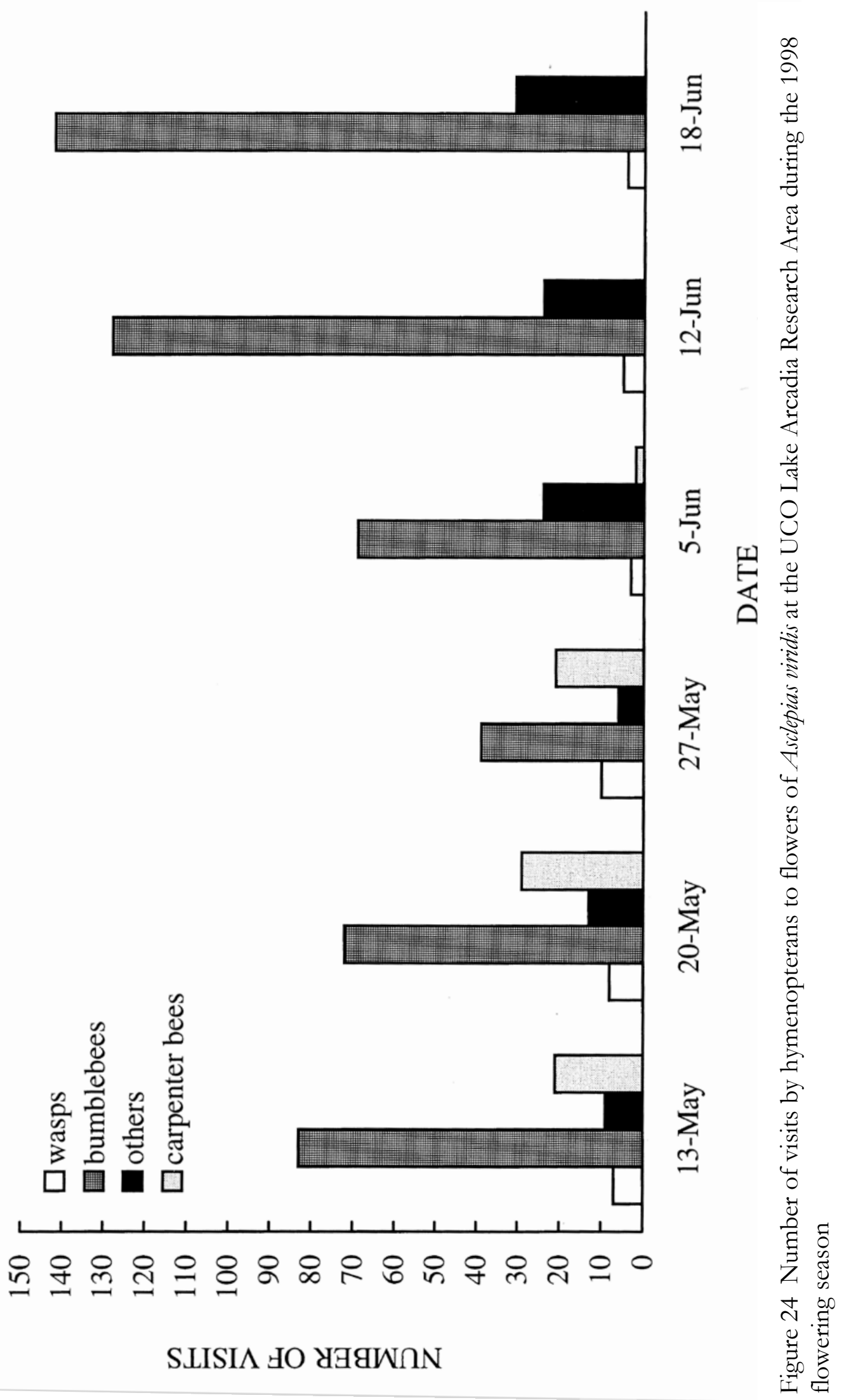


Table 5 Fruit-set percentages for four different types of pollinium insertions for Asclepias viridis

\begin{tabular}{cccc}
\hline \hline Type of insertion & \# attempted & \# of mature follicles ${ }^{*}$ & $\%$ \\
\hline VTS & 75 & 11 & 14.7 \\
VOS & 75 & 0 & 0.0 \\
HTG & 75 & 0 & 0.0 \\
HOG & 75 & 2 & 2.7 \\
\hline
\end{tabular}

\begin{abstract}
${ }^{*}$ Mature follicles were defined as follicles with fully developed seed when dehiscence occurs naturally.

Abbreviations: VTS, vertical insertion with the convex edge towards the stigmatic surface; VOS, vertical insertion with the convex edge opposite the stigmatic surface; HTG, horizontal insertion with the convex edge towards the ground; HOG, horizontal insertion with the convex edge opposite the ground.
\end{abstract}

\section{CONCLUSIONS}

The scanning electron microscope (SEM) study of the gynostegium provides the first three-dimensional observation of the spatial relationship between the gynoecium and androecium and also provides anatomical data to show that the most probable stigmatic surface is not within the stigmatic chambers but at the point of fusion of the two styles. The SEM pictures also show that pollen tubes from one chamber could enter either style. This may uncover the mystery of twinning in some Asclepias studied to date (Sparrow and Pearson 1948; Kephart 1981; Broyles and Wyatt 1990; Morse 1993) and suggest that chamber selection should be taken into account when pollinia are inserted if twinning is to be avoided.

Like some species of Asclepias investigated thus far (Wyatt and Broyles 1994), A. viridis appears to be entirely selfincompatible. Therefore, it is not surprising to obtain a low percent of natural fruit-set, an average of $1.6 \%$ in this study, even when pollinator insufficiency is excluded. Many of the pollinaria inserted into flowers may contain incompatible pollen. In addition, although resource limitation resulting in follicle abortion is another factor limiting follicle production in this natural population, other factors such as flower and follicle predation and plant diseases also contribute to the low natural fruit-set.

Lack of pollination does not appear to limit fruit-set in $A$. viridis. Of flowers collected, 91\% had been pollinated, and supplemental pollination did not enhance fruit- or seed-set. Unlike other angiosperms that disperse pollen individually, several hundred pollen grains of Asclepias are dispersed and deposited in the stigmatic chambers as a unit by vectors. Not only is a single pollinium sufficient to produce a follicle, but it also can occasionally result in production of twin follicles. My anatomical observations of the gynostegium show that some pollen tubes grew on the stigmatic surface along the style instead of entering a stylar canal. This suggests that pollen tubes from a previously inserted pollinium may fully occupy the stylar canal. Consequently, pollen tubes from a second or a third inserted pollinium may be rejected and forced to grow along the styles. Nevertheless, further anatomical observations of the growth of pollen tubes 
into the styles are needed to support this viewpoint.

Many studies of hand-pollinations for Asclepias have been accomplished in greenhouses in which many environmental conditions, such as temperature, humidity, plant diseases, and predation, can be controlled to minimize the variables affecting results. The average success of intrapopulation crosses in this study was lower than in other published records for Asclepias. This may be due to intrinsic factors such as incompatibility of alleles and timing of nectar secretion or extrinsic factors such as humidty and temperature, which may dramatically affect the sugar concentration in nectar throughout a day and indirectly affect germination of pollen.

In agreement with other studies (Frost 1965; Macior 1965; Fishbein and Venable 1996), my data on flower-visiting taxa of A. viridis, including pollinaria carried by vectors and their visitation rates, indicate that hymenopterans are the most common pollinators associated with Asclepias. Among those, Bombus spp. are the most important because of their high visitation rate and ability to carry pollinaria. However, their pollination effectiveness in the population is still uncertain due to the lack of data on pollinia removal and insertion rates for this group alone. Large carpenter bees and some wasps also appear to function as pollinators. Many visitors of other families are suspected to be nectar robbers based on their visiting behavior such as idleness or long residence time on a single flower (small-sized lepidopterans and halictid bees), small body size mismatched to the flowers of $A$. viridis (halictid bees), and reduced tarsal hairs (paper wasps).

Many studies (Pleasants 1980; Gross and Werner 1983; Kephart 1983; Campbell 1985) suggest that insect visits to flowers are often associated with flowering phenology, and flowers within species or between species may, therefore, compete for pollinators when flower densities increase among species in a community. Combining my data on phenology and insect visitation, the visitation rate decreased as the flower density increased early in the flowering season, and the visitation rate of insect taxa increased as flower density decreased towards the late flowering season. Therefore, competition for pollination among individuals of $A$. viridis may occur.

In terms of the reproductive strategies of $A$. viridis, many factors, such as genetic barriers, timing of pollination, timing of nectar secretion, and resource limitation, appear to determine which pollinia result in mature follicles. Therefore, most flowers would play the role of pollen donor rather than pollen recipient. Furthermore, a successful cross-pollination of Asclepias may be primarily affected by the concentration of nectar. Whether genetic barriers or resource limitation play a major role in controlling fruit-set in a population of Asclepias is an interesting question to be studied in the future.

\section{ACKNOWLEDGEMENTS}

I tremendously thank Dr. G. M. Caddell for devoting her precious time to direct this project and revise and make comments on the earlier drafts of the thesis. Comments on the final draft of the thesis made by Dr. J. Barthell, who also helped confirm insect identifications, and Dr. D. Zanowiak are gratefully acknowledged. I especially thank Dr. D. Elmendorf for technical advice on use of the scanning electron microscope and for providing the photograph of pollinaria linkages of Asclepias viridis on a bumblebee. Laboratory facilities and supplies were provided by the Department of Biology of the University of Central Oklahoma. 


\section{LITERATURE CITED}

Baskin, J.M. and C.C. Baskin. 1977.

Germination of common milkweed

(Asclepias syriaca L.) seeds. Bulletin of the Torrey Botanical Club 104:167-170.

Bertin, R.I. and M.F. Willson. 1980. Effectiveness of diurnal and nocturnal pollination of two milkweeds. Canadian Journal of Botany 58:1744-1746.

Bookman, S.S. 1983a. Cost and benefits of flower abscission and fruit abortion in Asclepias speciosa. Ecology 64:264-273.

Bookman, S.S. 1983b. Effects of pollination timing on fruiting in Asclepias speciosa Torr. (Asclepiadaceae). American Journal of Botany 70:897-905.

Bookman, S.S. 1984. Evidence for selective fruit production in Asclepias. Evolution 38:72-86.

Brown, A.H.D, J.E. Grant, and R. Pullen. 1986. Outcrossing and paternity in Glycine argyrea by paired fruit analysis. Biological Journal of the Linnaean Society 29:283-294.

Broyles, S.B. and R. Wyatt. 1990. Paternity analysis in a natural population of Asclepias exaltata: Multiple paternity, functional gender, and the "pollendonation hypothesis." Evolution 44:1454-1468.

Broyles, S.B. and R. Wyatt. 1991. Effective pollen dispersal in a natural population of Asclepias exaltata: The influence of pollinator behavior, genetic similarity, and mating success. American Naturalist 138:1239-1249.

Broyles, S.B. and R. Wyatt. 1993. The consequences of self-pollination in Asclepias exaltata, a self-incompatible milkweed. American Journal of Botany 80:41-44.

Campbell, D.R. 1985. Pollinator sharing and seed set of Stellaria pubera: Competition for pollination. Ecology 66:544-553.

Ciampolini, F., K.R. Shivanna, and M. Cresti. 1990. The structure and cytochemistry of the postil of Sternbergia lutea (Amaryllidaceae). Annals of Botany 66:703-712.

Ellstrand, N.C. 1984. Multiple paternity within the fruits of the wild radish, Raphanus sativus. American Naturalist 123:819-828.

Fishbein, M. and D.L. Venable. 1996. Diversity and temporal change in the effective pollinators of Asclepias tuberosa. Ecology 77:1061-1073.

Frost, S.W. 1965. Insects and pollinia. Ecology 46:556-559.

Gold, J.J. and J.S. Shore. 1995. Multiple paternity in Asclepias syriaca using a paired-fruit analysis. Canadian Journal of Botany 73:1212-1216.

Gross, R.S. and P.A. Werner. 1983. Relationships among flowering phenology, insect visitors, and seed-set of individuals: Experimental studies on four co-occurring species of goldenrod (Solidago: Compositae). Ecological Monographs 53:95-117.

Jennersten, O. and D.H. Morse. 1991. The quality of pollination by diurnal and nocturnal insects visiting common milkweed, Asclepias syriaca. American Midland Naturalist 125:18-28.

Kahn, A.P. and D.H. Morse. 1991. Pollinium germination and putative ovule penetration in self- and crosspollinated common milkweed Asclepias syriaca. American Midland Naturalist 126:61-67.

Kearns, C.A. and D.W. Inouye. 1993. Techniques for Pollination Biology. Niwot (CO): The University Press of Colorado.

Kephart, S.R. 1981. Breeding systems in Asclepias incarnata L., $A$. syriaca L., and $A$. verticillata L. American Journal of Botany 68:226-232.

Kephart, S.R. 1983. The partitioning of pollinators among three species of Asclepias. Ecology 64:120-133.

Kevan, P.G., D. Eisikowitch, and B. Rathwell. 1989. The role of nectar in the germination of pollen in Asclepias syriaca L. Botanical Gazette 150:266-270. 
Lord, E.M. and L.U. Kohorn. 1986. Gynoecial development, pollination, and the path of pollen tube growth in the tepary bean, Phaseolus acutifolius. American Journal of Botany 73:70-78.

Macior, L.W. 1965. Insect adaptation and behavior in Asclepias pollination. Bulletin of the Torrey Botanical Club 92:114-126.

Morse, D.H. 1985. Milkweeds and their visitors. Scientific American 253:112-119.

Morse, D.H. 1987. Roles of pollen and ovary age in follicle production of the common milkweed Asclepias syriaca. American Journal of Botany 74:851-856.

Morse, D.H. 1993. The twinning of follicles by common milkweed Asclepias syriaca. American Midland Naturalist 130:56-61.

Newton, L.E. 1984. Terminology of structures associated with pollinia of the Asclepiadaceae. Taxon 33:619-621.

Oegema, T. and R.A. Fletcher. 1972. Factors that influence dormancy in milkweed seeds. Canadian Journal of Botany 50:713-718.

Pleasants, J.M. 1980. Competition for bumblebee pollinators in Rocky Mountain plant communities. Ecology 61:1446-1459.

Pleasants, J.M. 1991. Evidence for shortdistance dispersal of pollinia in Asclepias syriaca L. Functional Ecology 5:75-82.

Price, M.V. and N.M. Waser. 1979. Pollen dispersal and optimal outcrossing in Delphinium nelsoni. Nature 277:294-296.

Queller, D.C. 1985. Proximate and ultimate causes of low fruit production in Asclepias exaltata. Oikos 44:373-381.

Sage, T.L., S.B. Broyles, and R. Wyatt. 1990. The relationship between the five stigmatic chambers and two ovaries of milkweed (Asclepias amplexicaulis Sm.) flowers: A three-dimensional assessment. Israel Journal of Botany 39:187-196.

Schoen, D.J. 1985. Correlation between classes of mating events in two experimental plant populations. Heredity 55:381-385.
Shannon, T.R. and R. Wyatt. 1986. Reproductive biology of Asclepias exaltata. American Journal of Botany 73:1120.

Shore, J.S. 1993. Pollination genetics of the common milkweed, Asclepias syriaca L. Heredity 70:101-108.

Sobrevila, C. 1988. Effects of distance between pollen donor and pollen recipient on fitness components in Espeletia schultzii. American Journal of Botany 75:701-724.

Sokal, R.R. and F.J. Rohlf. 1981. Biometry. San Francisco (CA): W.H. Freeman and Co.

Sparrow, F.K. and N.L. Pearson. 1948. Pollen compatibility in Asclepias syriaca. Journal of Agricultural Research 77:187-199.

Sundell, E. 1984. A. T. Brongniart's interpretation of the milkweed flower. Taxon 33:614-618.

Walters, D.R. and D.J. Keil. 1996. Vascular Plant Taxonomy. Dubuque (IA): Kendall Hunt Publishing Co.

Waser, N.M. 1983. Competition for pollination and floral character differences among sympatric plant species: A review of evidence. In: Jones, C.E. and R.J. Little (eds.). Handbook of Experimental Pollination Biology. Scientific and Academic Editions. New York (NY): Van Nostrand Reinhold Co. pp. 277-293.

Waser, N.M. and M.V. Price. 1983. Optimal and actual outcrossing in plants, and the nature of plant-pollinator interaction. In: Jones, C.E. and R.J. Little (eds.). Handbook of Experimental Pollination Biology. Scientific and Academic Editions. New York (NY): Van Nostrand Reinhold. pp. 341-359.

Wilbur, H.M. 1976. Life history evolution in seven milkweeds of the genus Asclepias. Journal of Ecology 64:223-240.

Willson, M.F. and R.I. Bertin. 1979. Flowervisitors, nectar production, and inflorescence size of Asclepias syriaca $\mathrm{L}$. Canadian Journal of Botany 57:1380-1388. 
Willson, M.F., R.I. Bertin, and P.W. Price. 1979. Nectar production and flower visitors of Asclepias verticillata. American Midland Naturalist 102:23-35.

Willson, M.F. and P.W. Price. 1977. The evolution of inflorescence size in Asclepias (Asclepiadaceae). Evolution 31:495-511.

Willson, M.F. and P.W. Price. 1980.

Resource limitation of fruit and seed production in some Asclepias species. Canadian Journal of Botany 58:2229-2233.

Willson, M.F. and B.J. Rathcke. 1974. Adaptive design of the floral display in Asclepias syriaca L. American Midland Naturalist 92:47-57.
Woodson, R.E. 1947. Some dynamics of leaf variation in Asclepias tuberosa. Annals of the Missouri Botanical Garden 34:353432.

Woodson, R.E. 1954. The North American species of Asclepias L. Annals of the Missouri Botanical Garden 41:1-211.

Wyatt, R. 1976. Pollination and fruit-set in Asclepias: A reappraisal. American Journal of Botany 3:845-851.

Wyatt, R. and S.B. Broyles. 1994. Ecology and evolution of reproduction in milkweeds. Annual Review of Ecology and Systematics 25:423-441.

Zar, J.H. 1984. Biostatistical Analysis. Englewood Cliffs (NJ): Prentice-Hall, Inc./Simon \& Schuster Co. 